\title{
ABCG2: determining its relevance in clinical drug resistance
}

\author{
Robert W. Robey • Orsolya Polgar • John Deeken • \\ Kin Wah To $\cdot$ Susan E. Bates
}

Published online: 24 February 2007

(C) Springer Science + Business Media, LLC 2007

\begin{abstract}
Multidrug resistance is a major obstacle to successful cancer treatment. One mechanism by which cells can become resistant to chemotherapy is the expression of $\mathrm{ABC}$ transporters that use the energy of ATP hydrolysis to transport a wide variety of substrates across the cell membrane. There are three human ABC transporters primarily associated with the multidrug resistance phenomenon, namely Pgp, MRP1, and ABCG2. All three have broad and, to a certain extent, overlapping substrate specificities, transporting the major drugs currently used in cancer chemotherapy. ABCG2 is the most recently described of the three major multidrug-resistance pumps, and its substrates include mitoxantrone, topotecan, irinotecan, flavopiridol, and methotrexate. Despite several studies reporting $\mathrm{ABCG} 2$ expression in normal and malignant tissues, no trials have thus far addressed the role of ABCG2 in clinical drug resistance. This gives us an opportunity to critically review the disappointing results of past clinical trials targeting Pgp and to propose strategies for ABCG2. We need to know in which tumor types ABCG2 contributes to the resistance phenotype. We also need to develop standardized assays to detect ABCG2 expression in vivo and to carefully select the chemotherapeutic agents and clinical trial designs. This review focuses on our current knowledge about normal tissue distrubution, tumor expression profiles, and substrates and inhibitors of ABCG2, together with lessons learned from clinical trials with Pgp inhibitors. Implications of SNPs in the $A B C G 2$ gene affecting the pharmacokinetics of substrate drugs, including
\end{abstract}

R. W. Robey $\cdot$ O. Polgar $\cdot$ J. Deeken $\cdot$ K. W. To $\cdot$ S. E. Bates $(\triangle)$ Medical Oncology Branch, Center for Cancer Research,

National Cancer Institute, National Institutes of Health,

Bethesda, MD 20892, USA

e-mail: sebates@helix.nih.gov many non-chemotherapy agents and ABCG2 expression in the SP population of stem cells are also discussed.

Keywords $\mathrm{ABCG} 2 \cdot$ Multidrug resistance $\cdot \mathrm{ABC}$ transporters

\section{Introduction}

Clinical drug resistance remains a significant impediment to the successful treatment of cancer. The multidrug resistance phenotype is often associated with increased expression of ATP-binding cassette (ABC) transporters that mediate energy-dependent transport of substrate drugs out of the cell against a concentration gradient [1]. The discovery of the MDR1 $(A B C B 1)$ gene 20 years ago $[2,3]$ ignited a fervent study of drug resistance in cancer. As a result, the protein encoded by MDRl, P-glycoprotein (Pgp), is by far the most intensely studied $\mathrm{ABC}$ transporter. Pgp is known to transport a wide range of chemotherapeutic agents including the anthracyclines, vincas, taxanes, etoposide, and mitoxantrone [1]. Despite strong evidence linking Pgp expression to poor prognosis in diseases such as leukemia, early clinical trials aimed at inhibiting Pgp were poorly designed and unsuccessful [4], leading many to abandon the idea of reversing Pgp-mediated resistance. Most later trials utilizing "second generation" inhibitors were equally unsuccessful. Several explanations for the difficulty in confirming the MDR hypothesis at the level of the clinical trial can be invoked [4].

In 1993, Cole and colleagues cloned a gene encoding another energy-dependent transporter, the multidrug resistance-associated protein, or MRP1 (ABCC1) [5]. Conferring resistance to a somewhat narrower range of chemotherapy agents, namely the anthracyclines, vincas, etoposide and 
teniposide, MRP1 renewed interest in $\mathrm{ABC}$ transporters, especially since MRP1 expression is frequently observed in non-small cell lung cancer [6, 7]. However, few MRP1specific inhibitors were developed and the lack of success of clinical trials attempting to reverse Pgp-mediated drug resistance left many hesitant to attempt studies to inhibit MRP1 clinically.

In the early 1990 s, several groups began reporting nonPgp, non-MRP1-mediated drug resistance in a variety of drug-selected cell lines [8-12]. The resistant cell lines exhibited resistance to doxorubicin and etoposide in addition to high mitoxantrone resistance, but lacked resistance to vinblastine or cisplatin. In one drug-selected cell line, high levels of cross-resistance to the camptothecin analogs topotecan, 9-aminocamptothecin, CPT-11, and SN38 , the active metabolite of CPT-11, were also found [13].

The gene responsible for the novel cross-resistance phenotype was first cloned by Doyle and colleagues from the MCF-7 AdrVp breast cancer cell line developed in the Fojo laboratory [14] and was called $B C R P$ for breast cancer resistance protein [15]. Shortly thereafter, Allikmets and colleagues reported a nearly identical gene termed $A B C P$ for ATP-binding cassette transporter expressed in placenta [16]; and our laboratory reported a cDNA cloned from the mitoxantrone-selected colon carcinoma cell line S1-M1-80 and termed the gene $M X R$, or mitoxantrone resistance gene [17]. When the sequences were eventually compared, they were recognized as essentially identical and belonging to a subfamily of $\mathrm{ABC}$ transporters not previously associated with drug resistance in humans.

Subsequent to the cloning of $B C R P / A B C P / M X R$, the Human Genome Nomenclature Committee assigned the gene the name ABCG2, making it the second gene in the $\mathrm{G}$ subfamily of $A B C$ transporters that is made up of only halftransporters. This terminology will be used throughout this review. The G subfamily of transporters contains five other members in addition to ABCG2 [18]: two involved in cholesterol transport, $\mathrm{ABCG} 4$ and $\mathrm{ABCG1}$, the human homologue of the Drosophila white protein [19]; one currently found only in rodents, Abcg3, which appears to have an aberrant ATP-binding domain [20]; and two that heterodimerize with each other to form a functional sterol transporter, ABCG5 and ABCG8 [21].

Eight years after the discovery of ABCG2, we still have no clear idea what role ABCG2 plays in clinical drug resistance. Determining this role will be critical in planning future clinical trials. In this review, we will characterize the resistant phenotype conferred by ABCG2, present reports of normal tissue distribution and discuss studies directed at determining the contribution of ABCG2 to drug resistance in cancer. A summary of the current methods used to measure the levels of ABCG2 in patient samples will be provided and we will make recommenda- tions on how to improve the reliability of data generated in future studies.

\section{Chromosomal localization and mechanisms controlling expression}

The $A B C G 2$ gene spans over $66 \mathrm{~kb}$ and is made up 16 exons and 15 introns; the resulting protein is 655 amino acids long and runs as a $72 \mathrm{kDa}$ protein on an SDS gel under reducing conditions [22]. Fluorescence in situ hybridization studies with a bacterial artificial chromosome probe containing $A B C G 2$ localized the gene to $4 \mathrm{q} 21-4 \mathrm{q} 22$ in cells with a normal chromosome 4 [23].

Few data are available regarding molecular mechanisms controlling $A B C G 2$ expression, but recent studies suggest that, in different systems, expression may be controlled at the promoter level by sex hormones, hypoxia and methylation status. Conflicting data exist with regard to the effect of the sex hormones estrogen, progesterone, and testosterone on ABCG2 expression [24-27], but all reports note some effect. Additionally, ABCG2 expression is upregulated in the mammary gland during lactation [28]. Krishnamurthy and colleagues were the first to demonstrate that hypoxia regulates ABCG2 expression [29]. They posit that stem cells or tumor cells in hypoxic environments may be protected from chemotherapeutic agents due to the increased levels of ABCG2 induced by hypoxia [29]. In a multiple myeloma system as well as a renal carcinoma system, ABCG2 promoter hypermethylation was linked to a decrease in ABCG2 expression [30, 31]. Further research is still needed to accurately characterize the mechanisms controlling $\mathrm{ABCG} 2$ expression.

\section{ABCG2 expression in normal tissues}

The discovery of ABCG2 led to several subsequent reports investigating expression in normal tissues. The initial report of Doyle and colleagues noted the highest level of ABCG2 expression in the placenta, with lower levels in the brain, prostate, small intestine, testis, ovary, colon and liver, as determined with a cDNA probe [15]. The development of antibodies to $\mathrm{ABCG} 2$ enabled the detection of $\mathrm{ABCG} 2$ in formalin-fixed, paraffin-embedded tissues. Maliepaard et al examined ABCG2 expression in normal tissues and cancer cell lines using the BXP-21 and BXP-34 monoclonal antibodies. ABCG2 expression was found in the placenta, particularly in the synctiotrophoblastic cells, as well as in the colon, small intestine, biliary canaliculi, breast tissue, venous endothelium, and in capillaries [32]. Our laboratory subsequently developed a polyclonal anti-ABCG2 antibody (termed 87405 or 405) [33] and observed high ABCG2 
expression in the alveolar pneumocytes, sebaceous glands, small and large intestine, islet and acinar cells of the pancreas, zona reticularis of the adrenal gland, hepatocytes, cortical tubules of the kidney, and prostate epithelium in addition to previously reported sites [34]. These tissue localization studies suggested a protective role for $\mathrm{ABCG} 2$, and for some tissues, further work has supported this theory.

\subsection{Placenta}

Since high levels of ABCG2 have been observed in synctiotrophoblasts at the chorionic villus [32, 34], it has been postulated that ABCG2 forms part of the maternalfetal barrier, serving to protect the fetus from endogenous and exogenous toxins. Jonker and colleagues demonstrated that, when the dual Pgp and ABCG2 inhibitor elacridar (GF120918) was administered with topotecan to Abcb1/2-deficient pregnant mice, fetal plasma topotecan levels were twice those of mice treated with topotecan alone, supporting a protective role for $\mathrm{ABCG} 2$ in the placenta [35]. The use of $A b c b 1 / 2$-deficient, thus Pgpdeficient, mice in these studies allowed the authors to isolate the ABCG2 transporter for study; as topotecan is a substrate for both Pgp and ABCG2, and elacridar is an inhibitor of Pgp as well as ABCG2. In placenta perfusion studies, Staud et al demonstrated transport of the ABCG2 substrate cimetidine from the fetal to the maternal space against a concentration gradient [36]. They suggest that ABCG2 in the placenta serves to reduce passage of substrates from mother to fetus as well as to reduce substrates in the fetal circulation [36].

\subsection{Mammary gland}

Surprisingly, ABCG2 expression in the mammary gland has been found to concentrate substrates, including toxins, into breast milk. Jonker et al found ABCG2 expression was induced in the lactating mammary glands of mice, cows and humans, and reported higher levels of topotecan and the carcinogen 2-amino-1-methyl-6-phenylimidazo[4, 5-b]pyridine (PhIP) in the milk of lactating wild-type mice compared to Abcg2-deficient mice [28]. ABCG2 has also been shown to concentrate the carcinogen aflatoxin B1 [37] as well as antibiotics [38] into breast milk. The reason why ABCG2 is induced in the lactating mammary gland has yet to be elucidated.

\subsection{Testis}

We have reported high levels of ABCG2 in the interstitial cells of the normal testis as well as in Sertoli/Leydig cells [34]. Bart and colleagues have also reported high ABCG2 expression by myoid cells and cells of the luminal capillary endothelial wall of the normal testis [39]. Lasalle and colleagues have reported ABCG2 expression in germinal stem cells, again suggesting a role in protection against genotoxic mutagens [40].

\subsection{Blood-brain barrier}

ABCG2 appears to form part of the blood-brain barrier along with Pgp. Cooray et al found high ABCG2 expression at the luminal surface of the microvessel endothelium, suggesting a protective role, much like Pgp [41]. Brain vessels extracted from nonmalignant human brain tissue have been shown to have higher expression of ABCG2 compared to Pgp or MRP1 [42]. Similarly, Cisternino et al reported 700-fold higher Abcg2 expression in the mouse brain microvasculature compared to the cortex in wild-type mice [43]. Additionally, they found brain microvasculature Abcg2 expression to be 3-fold higher in Abcb1-deficient mice compared to wild-type, suggesting that ABCG2 upregulation may occur as a compensatory mechanism [43]. Preliminary studies have shown that inhibition of ABCG2 in addition to Pgp may improve brain penetration of some drugs [44]. However, the multifaceted, complex nature of the blood-brain barrier will probably limit the uptake of most, if not all, substrates [45] and the CNS will remain a sanctuary site. This is a strategy desperately in need of development, as a number of important substrates are limited in their CNS uptake. These include some HIV protease inhibitors and numerous anticancer agents known to be substrates for both Pgp and ABCG2 [45].

\subsection{Gastrointestinal tract}

Initial studies reporting the presence of ABCG2 in the small intestine and subsequent immunohistochemical studies localizing ABCG2 to the epithelium of the small intestine implied a potential role for $\mathrm{ABCG} 2$ in substrate absorption $[15,32]$. Jonker and colleagues were the first to confirm a role for $\mathrm{ABCG} 2$ in the oral absorption of substrate drugs. They administered oral topotecan in the presence or absence of elacridar and found significantly higher plasma drug levels in mice receiving elacridar [35]. Additionally, elacridar decreased plasma drug clearance, decreased hepatobiliary excretion and increased re-uptake in the small intestine [35]. Again, Abcb1/2-deficient mice were used in the study. A subsequent clinical trial confirmed the ability of elacridar to increase oral bioavailability of topotecan in humans [46]. Inhibition of ABCG2 by coadministration of gefitinib, known to inhibit $\mathrm{ABCG} 2$, with irinotecan resulted in a $63 \%$ increase in the oral bioavailability of irinotecan in mice [47]. The area under the concentration curve for the orally administered ABCG2 substrate PhIP was found to be nearly 3-fold higher in Abcg2-deficient mice compared to 
wild-type mice, suggesting that $\mathrm{ABCG} 2$ limits exposure to this dietary carcinogen [48].

Taken together, these studies suggest a major role for ABCG2 in limiting the oral absorption of drugs. In fact, the expression of Pgp in the gut has long been appreciated and studies have attempted to discover the impact of inhibiting Pgp on the oral bioavailability of drugs; however, expression of other transporters or detoxifying enzymes has sometimes led investigators to question the effect of Pgp on bioavailability $[49,50]$. Further, studies correlating drug absorption with single nucleotide polymorphisms thought to alter Pgp expression levels in the gut have not yielded consistent results [51]. If the data emerging from ABCG2 studies do not reflect early publication bias, but rather an actual clinical impact of ABCG2 on drug absorption, the results are remarkable.

\subsection{Hematopoietic stem cells}

Hematopoietic stem cells had previously been characterized by transport of the fluorescent compound Hoechst 33342, recognized as the "side population" or SP when isolated by flow cytometry [52]. Zhou et al were the first to report Abcg2 to be responsible for the transport of Hoechst dye in murine hematopoietic stem cells [53] and Scharenberg and colleagues showed $\mathrm{ABCG} 2$ to be responsible in human cells [54]. Interestingly, ABCG2 is not required for normal hematopoiesis, as Abcg2-deficient mice are viable and have no hematologic abnormalities; however, Abcg2-deficient mice no longer display a SP phenotype $[55,56]$. Zhou and colleagues have shown that Abcg2-expression does serve to protect the bone marrow from toxins using a competitive repopulation assay [56].

Subsequent to studies in the bone marrow, a sidepopulation has been described for many normal tissues [57-61], although its role in these tissues has yet to be elucidated. Side population cells have also been identified in several cancer cell lines and primary tumor samples and have been shown to be resistant to ABCG2 substrates [6265]. This finding has led to the idea of an intrinsically resistant cancer stem cell (see below) that has been postulated to account for the resistance of cancer to chemotherapy.

\section{Substrates of ABCG2}

Since ABCG2 was first described in drug-resistant cell lines, a number of chemotherapeutic agents have been shown to be transported by the protein. Resistance to mitoxantrone is the hallmark of the phenotype conferred by
$\mathrm{ABCG} 2$ expression as is resistance to the camptothecin derivatives 9-aminocamptothecin, topotecan, irinotecan, and SN-38 (the active metabolite of irinotecan) [66, 67]. Selection with mitoxantrone [68], topotecan $[69,70]$ or SN38 [71] results in ABCG2 overexpression as does selection with flavopiridol [72]. Even selection with DX-8951f or BNP-1350, camptothecins that are relatively poor ABCG2 substrates, results in ABCG2 upregulation [73, 74]. Indolocarbazole topoisomerase I inhibitors $\mathrm{J}-107088$ and NB-506 [75] have been shown to be transported by ABCG2, as have the tyrosine kinase inhibitors CI1033 [76], gefitinib [77], and imatinib [78]. Overexpression of ABCG2 has also been shown to confer resistance to methotrexate and, to a lesser extent, methotrexate di- and triglutamate $[79,80]$. The antifolates Tomudex and GW1843 are also substrates of ABCG2 [81]. A summary of chemotherapeutic agents transported by $\mathrm{ABCG} 2$ is provided in Table 1.

One early mystery surrounding the cross-resistance profile conferred by ABCG2 overexpression concerned the transport of anthracyclines and the fluorescent compound rhodamine 123. In addition to high levels of cross-resistance to mitoxantrone, the drug-selected cell lines MCF-7 AdVp3000 and S1-M1-3.2 exhibited high levels of resistance to doxorubicin and transport of rhodamine was readily observed $[82,83]$. However, MCF-7 MX cells did not display equally high levels of cross-resistance to doxorubicin despite very high levels of resistance to mitoxantrone and high levels of ABCG2 protein expression [84]. In addition, we found that the MCF-7 MX cell line did not transport rhodamine 123 [84]. Upon sequencing the $A B C G 2$ gene in a series of parental and ABCG2-overexpressing cell lines, we found that cells with a glycine or threonine at amino acid 482 readily transported doxorubicin and rhodamine 123 in addition to mitoxantrone while cells that expressed wildtype ABCG2 with an arginine at position 482 only transported mitoxantrone [85]. Allen and colleagues reported mutation of the arginine at position 482 in mouse Abcg2 to a methionine or serine, suggesting it to be a "hot spot" for mutation [86]. Substitution of the various amino acids by site-directed mutagenesis at position 482 has shown that mutation of the wild-type arginine to almost any other amino acid results in this gain-of-function phenotype [87-89]. Mutations at amino acid 482 have also been shown to affect the potency of ABCG2 inhibitors [90, 91] as shown in Fig. 1. While it is possible that tumors harboring mutations in $\mathrm{ABCG} 2$ may turn out to be cross-resistant to a wider variety of chemotherapeutic agents than tumors that express wild-type ABCG2, amino acid 482 mutations have yet to be found in clinical samples, suggesting that this observation has limited clinical relevance. 
Table 1 Selected substrates and inhibitors of ABCG2

\begin{tabular}{|c|c|}
\hline Substrates & Inhibitors \\
\hline Mitoxantrone [66] & Fumitremorgin $\mathrm{C}[83,102]$ \\
\hline Daunorubicin $^{\mathrm{a}}[14,86,90,169]$ & Ko143 [103] \\
\hline Doxorubicin $^{\mathrm{a}}[14,83,86,90,169]$ & Cyclosporin A $[82,187,188]$ \\
\hline Epirubicin $^{\mathrm{a}}[90]$ & Tacrolimus [187] \\
\hline Bisantrene $^{a}[83,90]$ & Sirolimus [187] \\
\hline Flavopiridol $[72,170]$ & Gefitinib [110, 189-191] \\
\hline Etoposide $[10,11,14,171]$ & Imatinib $[191,192]$ \\
\hline Teniposide $[171]$ & Elacridar (GF120918) [106, 175] \\
\hline 9-aminocamptothecin [13, 172-175] & Tariquidar (XR9576) [107] \\
\hline $\begin{array}{l}\text { Topotecan }[13,69,70,173 \text {, } \\
175-177]\end{array}$ & Biricodar $^{\mathrm{a}}(\mathrm{VX}-710)$ [91] \\
\hline Irinotecan $[13,175,178,179]$ & Chrysin [113] \\
\hline $\begin{array}{l}\text { SN-38 }[13,71,172 \\
175,180,181]\end{array}$ & 6-prenylchrysin ${ }^{\mathrm{a}}[115]$ \\
\hline Diflomotecan $^{\mathrm{a}}[182]$ & Tectochrysin $^{a}[115]$ \\
\hline Homocamptothecin $^{\mathrm{a}}$ [182] & Naringenin [96] \\
\hline DX-8951f $[73,178]$ & Quercetin[111, 181] \\
\hline BNP1350 [74] & Acacetin $[96]$ \\
\hline $\mathrm{J}-107088[75]$ & Silymarin [111] \\
\hline NB-506 [75] & Genistein [96] \\
\hline UCN-01 [107] & $17\{$ beta $\}$-estradiol [193] \\
\hline Methotrexate $^{\mathrm{a}}$, methotrexate $\mathrm{di}^{\mathrm{a}}$ - and & Estrone [193] \\
\hline triglutamate $^{\mathrm{a}}[79-81,100,183,184]$ & Tamoxifen [194] \\
\hline $\mathrm{GW} 1843^{\mathrm{a}}[81]$ & Ortataxel [165] \\
\hline Tomudex $^{\mathrm{a}}[81]$ & Novobiocin $^{\mathrm{a}}[108,109]$ \\
\hline Imatinib [78] & Reserpine [53] \\
\hline Gefitinib [77, 110] & WK-X-34 [195] \\
\hline CI1033 [76] & Curcumin $[196,197]$ \\
\hline Pheophorbide a $[107,185]$ & Dipyridamole [198] \\
\hline $\begin{array}{l}\text { Pyropheophorbide a methyl ester } \\
{[186]}\end{array}$ & Nicardipene $[116,117,198]$ \\
\hline Chlorin e6 [186] & Nitrendipene $[116,117,198]$ \\
\hline Protoporphyrin IX [29, 186] & Nimodipene [198] \\
\hline
\end{tabular}

${ }^{a}$ Designates compounds known to be affected by the amino acid at position 482.

ABCG2 has also been shown to play a role in the transport of non-chemotherapeutic agents. It has been observed to be a factor in the biliary excretion of HMGCoA reductase inhibitors such as rosuvastatin [92], pitavastatin [93, 94], pravastatin [95] and cerivastatin [95]. The flavonoids genestein and quercetin have been shown to be transported by ABCG2 [96-98] as have several antibiotics [38, 99, 100]. Anthelmintic benzimidazoles have also been demonstrated to be ABCG2 substrates [101]. The expanding list of ABCG2 substrates highlights the fact that ABCG2 may play a significant role in pharmacology and points to a need for systematic studies aimed at identifying drugs that have ABCG2 as a principal modulator of oral absorption. The identification of SNPs, as outlined below, that reduce $\mathrm{ABCG} 2$ function makes this area of study a high priority in the effort to determine sources of interpatient variability in drug disposition.

\section{Inhibitors of ABCG2}

Interestingly, the first reported inhibitor of $\mathrm{ABCG}$, fumitremorgin $\mathrm{C}$ (FTC), was described before the gene had been cloned [83]. FTC, a diketopiperazine isolated from the fermentation broth of Aspergillus fumigatis, was first shown by Rabindran and colleagues to inhibit resistance in the mitoxantrone-selected S1-M1-3.2 colon cancer cell line [83]. Subsequently, FTC was shown to inhibit ABCG2-mediated transport of antineoplastics in stably-transfected MCF-7 cells [102]. The neurotoxicity of FTC prevented its clinical use, thus prompting the discovery of the FTC analogue Ko143 [103]. Other diketopiperazine inhibitors, including the indolyl diketopiperazines [104] and tryprostatin a [105], have also been described.

Several Pgp inhibitors have also been reported to inhibit ABCG2. We demonstrated that elacridar (GF120918) acts as an ABCG2 inhibitor [106], as does the potent Pgp inhibitor tariquidar (XR9576) [107]. As noted earlier, the ability of elacridar to inhibit ABCG2 in vivo was independently confirmed in studies with topotecan in Abcb1/2-deficient mice [35]. Reserpine has also been shown to inhibit ABCG2-mediated Hoechst 33342 transport in SP cells [53]. Minderman and colleagues have observed that biricodar (VX-710) is able to inhibit Pgp-, MRP1- and ABCG2-mediated transport [91].

The list of reported ABCG2 inhibitors has been growing rapidly. Novobiocin was identified early on as an ABCG2 inhibitor [108, 109]. Tyrosine kinase inhibitors have been shown to inhibit ABCG2, most likely as competitive inhibitors, since ABCG2 has been shown to directly transport or confer resistance to CI1033, gefitinib and imatinib [76-78, 110]. The flavonoids silymarin, hesperetin, quercetin and daidzein, as well as the stilbene resveratrol, were shown to increase intracellular accumulation of mitoxantrone and BODIPY-prazosin in ABCG2expressing cells [111]. Chrysin and biochanin a have also been shown to inhibit ABCG2 [112], in addition to [113] genestein, naringenin, acacetin and kaempferol [96]. Structure activity studies have also identified 6-prenylchrysin and tectochrysin as ABCG2 inhibitors [114, 115]. Dihydropyridines and pyridines have been shown by several groups to interact with ABCG2 [116, 117]. A summary of selected ABCG2 inhibitors is provided in Table 1. Despite the explosion of publications identifying ABCG2 inhibitors, none have been used in the clinical setting. 


\section{Single nucleotide polymorphisms (SNPs)}

Given the putative role of ABCG2 in pharmacology, SNPs and their impact on protein expression and function may have a direct impact on drug dosing and may play a role in response to treatment. While a number of SNPs have been reported, a nonsynonymous SNP at amino acid 141 resulting in a glutamine to lysine amino acid change has been studied extensively [118]. Various researchers have found that this SNP can lead to lower plasma membrane expression [119-122], reduced drug efflux [123, 124], and/ or reduced ATPase activity [122, 123]. Expression of the Q141K SNP in cell lines has been shown to lead to significantly lower IC50 values for ABCG2 substrates, including mitoxantrone, irinotecan, and SN-38 [119, 122]. The Q141K SNP has been shown to influence the pharmacokinetics of orally administered drugs, including topotecan [125], diflomotecan [126] and 9-aminocamptothecin [127]. As noted earlier, the higher plasma drug levels due to the Q141K SNP may result in exquisite sensitivity to certain orally administered chemotherapy drugs. While this could result in tumors being exposed to higher drug levels, eliciting a greater response to treatment, it could also cause increased toxicity. Which outcome prevails depends upon individual drug pharmacodynamics.

\section{Expression of ABCG2 in clinical samples}

In view of the fact that chemotherapeutic agents are readily transported by ABCG2, determining its relevance in drug resistance has become an important goal. Since leukemia samples are ideal for flow cytometric as well as PCR-based studies, several reports have surfaced that examine expression of ABCG2 in leukemic blasts. Ross and colleagues were the first to report on ABCG2 expression in a series of leukemia samples. They examined 20 acute myelogenous leukemia (AML) samples and one acute lymphocytic

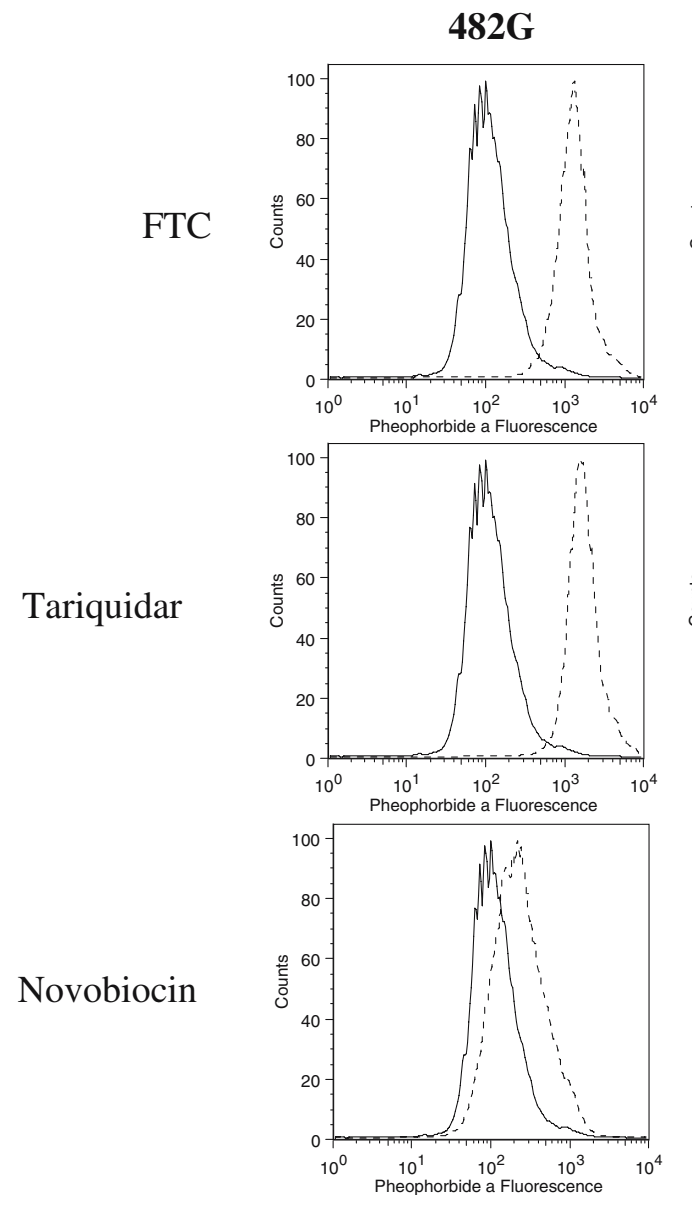

Fig. 1 Mutations at amino acid 482 of ABCG2 affect inhibitor efficacy. Human embryonic kidney cells (HEK-293) stably expressing wild-type (482R) or mutant (482G, 482T) were incubated with $1 \mu \mathrm{M}$ $\mathrm{PhA}$ in the presence of absence of $10 \mu \mathrm{M}$ FTC, $10 \mu \mathrm{M}$ tariquidar or $50 \mu \mathrm{M}$ novobiocin for $30 \mathrm{~min}$. Cells were then washed then allowed
$482 \mathrm{R}$
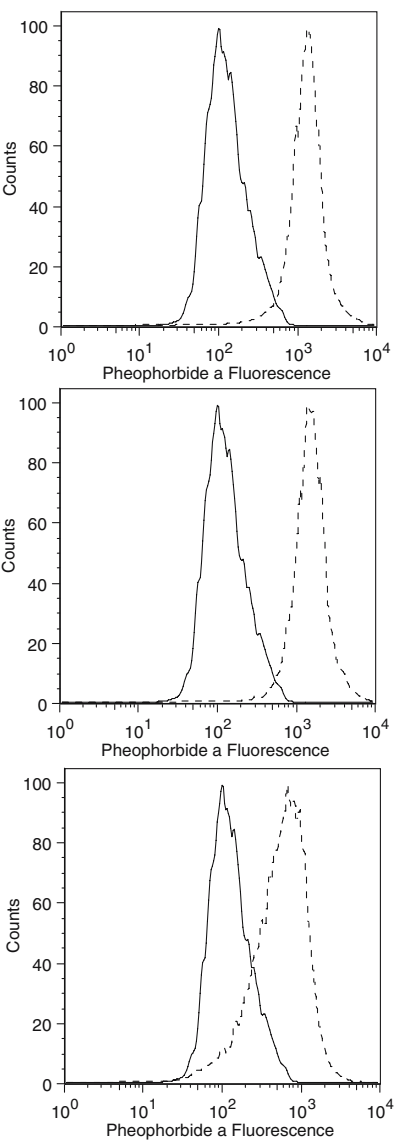

to incubate for $1 \mathrm{~h}$ in $\mathrm{PhA}$-free medium continuing with (dashed line) or without (solid line) inhibitor. Note that, while FTC and tariquidar completely inhibited all forms of the protein, denoted by the difference between the solid and dashed histograms, novobiocin was only able to completely inhibit wild-type (482R) protein 
leukemia (ALL) sample, finding relatively high expression in seven samples and a 1,000-fold variation in expression [128]. This early report seemed to suggest that ABCG2 expression might be a significant prognostic factor in leukemia. Since this initial report; however, results have varied widely, with relatively high ABCG2 expression in AML reported by some groups [129] and low levels reported by others [130-132]. Similarly, some groups reported ABCG2 expression was associated with response $[133,134]$ while others found no correlation [131]. In the largest study reported to date, with 149 patient samples, Benderra and colleagues reported that ABCG2 expression was predictive of complete remission 4-year disease-free survival, and 4-year overall survival in patients receiving daunorubicin or mitoxantrone [133].

It has also been suggested that ABCG2 might play a role in drug resistance in acute lymphoblastic leukemia (ALL). Steinbach et al reported a correlation between ABCG2 expression and prognosis [136]. Similarly, Stam et al reported $\mathrm{ABCG} 2$ expression correlated with resistance to Ara-C despite the fact that the drug is not an ABCG2 substrate [137]. In contrast, Sauerbrey and colleagues did not find a correlation between ABCG2 expression and response in childhood ALL [138].

To clearly delineate the role of ABCG2 in drug resistance in leukemia, larger studies of ABCG2 expression in clinical samples are necessary. Results available to date for studies in leukemic samples are reported in Table 2. Such studies have repeatedly shown over the past two decades that Pgp expression is important in leukemia [4]. While the precise clinical endpoint was not always the same, the conclusion was-Pgp impacted negatively on treatment outcome in AML. Fewer data exist for ALL. It would be a mistake to carry out further studies of ABCG2 in AML and ALL without also assessing Pgp expression. Methods for evaluating the impact of each transporter alone and together are needed. A recent cDNA array analysis of AML samples identified six subsets of AML based on their gene expression profile [139]. One of these subsets had notably higher Pgp and ABCG2 expression and was associated with the highest rate of resistant disease [139].

Reports of ABCG2 expression in solid tumors have begun to appear in the literature and Table 3 presents a summary of the clinical findings. The report of Diestra et al, examining ABCG2 expression in 150 paraffin-embedded, untreated tumor samples from various origins is by far the most extensive. They found frequent expression of ABCG2, especially in tumors from the digestive tract, endometrium, lung and melanoma [140]. Before a definitive answer can be reached regarding the contribution of ABCG2 to cancer drug resistance, larger studies such as these will be needed.
In breast cancer, the most widely studied tumor type, ABCG2 expression was relatively low and did not appear to correlate with clinical outcome in the studies of Kanzak et al [141] or Faneyte et al [142], but was correlated with response in patients treated with anthracyclines in the study by Burger et al [143]. This is a somewhat surprising result, as anthracyclines do not appear to be transported by ABCG2 [90]. Yoh et al reported that ABCG2 expression in non-small cell lung cancer was predictive of a lower response rate in patients receiving platinum-based chemotherapy [144], but, again, this is an unexpected result, since platinum compounds are not transported by ABCG2. Friedrich et al found that increased ABCG2 expression correlated with loss of differentiation and shorter survival in oral squamous cell carcinoma [145]. In studies of testicular tumors, Zurita et al and Diestra et al found no correlation between $\mathrm{ABCG} 2$ expression and response despite positive immunohistochemical staining in some samples [146, 147].

The finding that $\mathrm{ABCG} 2$ expression could correlate with clinical outcome when a non-ABCG2 substrate is being used is intriguing. At first glance, this might appear to be publication bias, wherein those of us interested in clinical correlates only follow up results that are statistically significant. Such early correlates often prove incorrect in followup studies. However, alternate explanations can be posed. For one, ABCG2 may be transporting a substrate that is necessary for cell death, thus mediating resistance without actually transporting the drug with which the tumor is treated. Alternatively, whatever the treating drug, the most sensitive cells in the tumor are eliminated leaving behind drug resistant cells. Tumors with higher levels of drug resistant cells will be more refractory, resulting in poor treatment outcome. What cells would be both ABCG2 expressing and drug resistant?

\section{Cancer stem cells}

The cancer stem cell theory is based on the idea that only a small fraction of tumor cells is capable of repopulating a tumor, much like hematopoietic stem cells found in bone marrow from which all blood cells differentiate. These cells are capable of long-term self renewal, divide slowly, are drug resistant, and express ABCG2 [148, 149]. The "side population" or "SP" phenotype has been used to identify bone marrow stem cells based on their ability to transport the fluorescent compound Hoechst 33342 [52]. As mentioned earlier, SP cells express high levels of ABCG2 and they thus appear dimmer than the rest of the cell population due to transport of Hoechst 33342 out of the cell [53]. Using Hoechst 33342 as a probe, SP cells have been found in normal breast, lung, and liver tissue [58, 59, 150] as well 


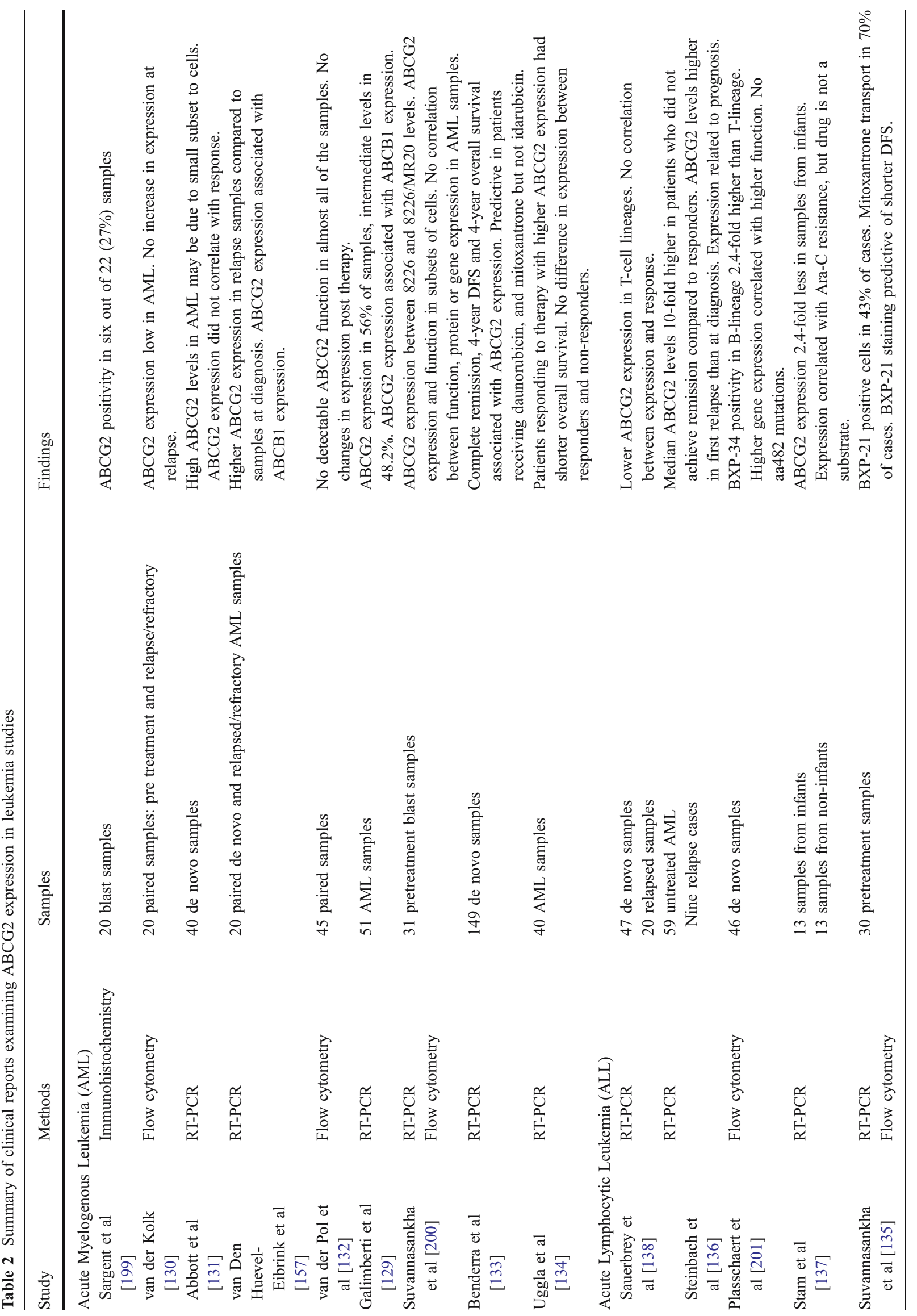




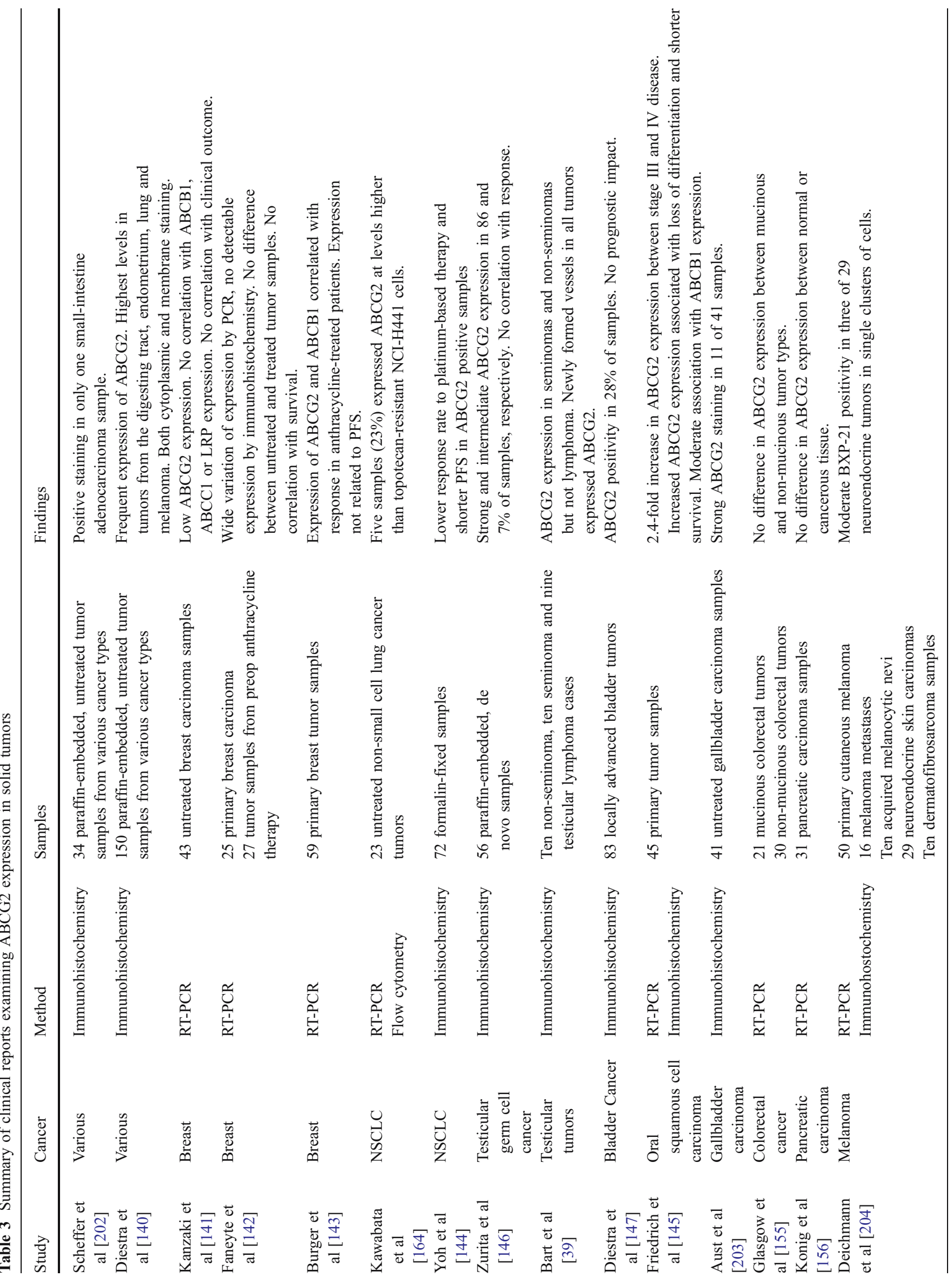


as in the corneal stroma [61]. SP cells have been found in a number of established tumor cell lines as well as tumor samples and have been shown to have stem cell-like qualities, overexpress $\mathrm{ABCG} 2$, and possess inherent drugresistance [62-65].

While some reports seem to suggest ABCG2 to be a marker of stem cells, several pieces of evidence suggest that ABCG2 expression alone does not define the stem cell population. First, ABCG2 expression is not an absolute requirement for stem cells. Abcg2-deficient mice are viable and demonstrate no defect in steady state hematopoiesis, although the bone marrow of Abcg2-deficient mice does lack an SP [56, 151]. Second, the SP fraction is not known to be a pure stem-cell population and the method used for generating SP cells greatly affects the cells included in it [152]. In some cases, ABCG2 expression is part of the normal differentiated phenotype; A549 cells have been shown to express ABCG2 and transport Hoechst 33342 [54] but the A549 cell line is not considered a "stem cell" line. Finally, drug-resistant cells that overexpress ABCG2 in response to selection pressure are not necessarily believed to be stem cells and ABCG2-positive and negative tumor cells have been reported to be similarly tumorigenic [153].

If an ABCG2-positive population of stem cells is, in fact, a characteristic of tumors, then they will most likely be a drug-resistant population of cells. Haraguchi and colleagues have shown SP cells to be more resistant to chemotherapeutic agents than non-SP cells in gastrointestinal cancer cell lines [65]. Similarly, Hirschmann-Jax et al. demonstrated increased mitoxantrone transport in SP cells obtained from neuroblastoma tumors as well as an increase in the SP fraction when neuroblastoma cell lines were treated with increasing concentrations of mitoxantrone [63]. Thus, the development of potent, specific inhibitors to target ABCG2-mediated transport may hold the key to eliminating this stem cell population.

\section{Avoiding mistakes of the past}

Two decades of Pgp research have not yet clarified the role of Pgp in drug resistance in the clinical setting. Reasons for this include the lack of validated assay methods, reliance on the clinical trial process to define the role of Pgp, and the possibility that other $\mathrm{ABC}$ transporters may be present, confounding clinical trial results. A major problem in assessing the significance of Pgp expression in clinical drug resistance has been the variability in measuring Pgp expression [154]. Despite the existence of several reliable methods to detect Pgp, findings often vary across laboratories, as evidenced by the results of a Pgp detection workshop [154]. Established, validated, widely-available, and consistent methods are still needed to further confirm the contribution of Pgp to clinical drug resistance. As the idea of $\mathrm{ABCG} 2$ as a mediator of drug-resistance is in its infancy, it is important that the same mistakes made with Pgp are avoided with ABCG2. Validated, standard, reproducible, and sensitive methodologies for detecting ABCG2 must be developed in order to characterize the role of $\mathrm{ABCG} 2$ in drug resistance.

\subsection{PCR}

PCR assays for ABCG2 detection have been carried out by several groups; however, there is no consistent cell line used as a reference. Comparing ABCG2 expression in patient samples to that of a well-characterized, stable cell line with low but detectable ABCG2 expression becomes important when trying to understand resistance conferred by ABCG2. Otherwise, the numbers generated by PCR analyses have no real meaning. While some PCR studies have included a low level ABCG2-expressing cell line such as MCF-7 [129, 131, 134, 136, 142], many do not include a reference at all $[135,155-157]$. While highly ABCG2positive cell lines can be included in the assay as a positive control, they should not be a substitute for cells expressing low levels. We recommend that the MCF-7 cell line, at the very least, be included in the analysis and, preferably, that more than one reference cell line be used as a control.

It is tempting to use highly drug-resistant cells as positive controls for an assay, but expression is usually so high that the levels are often not clinically relevant. Faneyte et al presented an elegant study of the breast cancer resistance profile in breast cancer by PCR analysis. Although the PCR assay was standardized to a drug-resistant cell line, several unselected cell lines were included. By PCR, the drugresistant cell line Igrov/T8 was assigned a value of 4.0 units and MCF-7 cells had a value of 0.48 units [142]. ABCG2 expression in the breast cancer samples examined averaged 0.18 units [142]. Furthermore, immunochemistry showed staining in normal duct cells, but not in breast cancer cells [142]. This result is reminiscent of the observations with Pgp in that normal cell expression exceeds that of the dedifferentiated cancer cell [158]. Taken together, Faneyte concluded that $\mathrm{ABCG} 2$ would not play a major role in drug resistance in breast cancer [142].

Present day studies of $\mathrm{ABC}$ transporters in drug resistance should also examine expression of multiple ABC transporters. Several excellent examples of such an effort to detect multiple transporter proteins have been reported [143, 157]. When Burger et al examined MDR-1, BCRP, LRP, MRP1, and MRP2 expression in 59 primary breast cancer samples by PCR, they concluded that MDR-1 expression was most closely associated with poor progres- 
sion-free survival [143]. These results supported the findings of a meta-analysis that concluded that Pgp was important in breast cancer outcome [159] and affirmed the results of Faneyte et al. A new marker of drug resistance apparently is not always better.

\subsection{Immunohistochemistry}

Several antibodies are available for detection of ABCG2 by immunohistochemistry. Maliepaard and colleagues developed the BXP-21 antibody that is able to detect ABCG2 by immunoblot and in formalin-fixed, paraffinembedded tissue samples [70]. The monoclonal 5D3 antibody, reported by Zhou and colleagues [53], recognizes an external epitope of $\mathrm{ABCG} 2$ and our laboratory has successfully used it to detect ABCG2 on formalin-fixed, paraffin-embedded tissue samples [34]. The polyclonal antibody 87405 (or 405) was developed in our laboratory using an immunizing peptide [33]. The antibody detects ABCG2 by immunoblot as well as in formalin-fixed, paraffin embedded tissues [33, 34], but is unable to detect ABCG2 by flow cytometry. Additionally, 87405 can detect ABCG2 in humans as well in mice, pigs, cows, and sheep $[160,161]$.

As suggested for PCR studies, several cell lines that express low but detectable levels of ABCG2 should be used to assess the sensitivity of the antibodies used. The MCF-7 cell line is again an ideal choice, although levels may be too low for reproducible detection, thus rendering immunohistochemistry a rather insensitive method. Tissues known to express ABCG2, such as the placenta or skin (sebaceous glands), may be included as positive controls. It will be interesting to see whether ABCG2 parallels Pgp in being higher in differentiated tissue. Pgp is higher in adjacent normal tissue than in cancer tissue due to the dedifferentiation that occurs in cancer [158]. So the inclusion of placenta tissue as a positive control in PCR or immunoblot analyses could result in setting up an assay to be relatively insensitive [162]. Particularly for polyclonal antibodies, the peptide used to generate the antibody should be used to verify that the observed staining is not background. Until the antibodies used for immunohistochemistry are better characterized, at least two antibodies should be used to ensure internal consistency of the results. It appears BXP-34 is not as sensitive as BXP-21 in immunohistochemical studies [140].

\subsection{Flow cytometry}

Functional assays for ABCG2 have been developed using fluorescent $\mathrm{ABCG} 2$ substrates and an $\mathrm{ABCG} 2$ inhibitor.
While assaying transporter function by flow cytometry can be quite reliable, and can in some ways be considered the "gold standard" since it measures actual transporter function, the assay has limitations, mostly due to the fact that the fluorescent compounds used are substrates for multiple transporters. Mitoxantrone and BODIPY-prazosin were among the first substrates used in flow-cytometry based assays for ABCG2 function [84, 163]. Transport of topotecan has also been shown to correlate with ABCG2 expression [164]. However, as mitoxantrone, BODIPYprazosin, and topotecan are also substrates of Pgp [84, 165], these substrates may not be useful in samples where other transporters are expressed at high levels. The porphyrin pheophorbide a $(\mathrm{PhA})$ has been identified as an ABCG2specific substrate, as it was not found to be transported by Pgp or MRP1 [107]; however, we have not examined whether it is transported by other $\mathrm{ABC}$ transporters. If confirmed, pheophorbide a would be an ideal substrate for
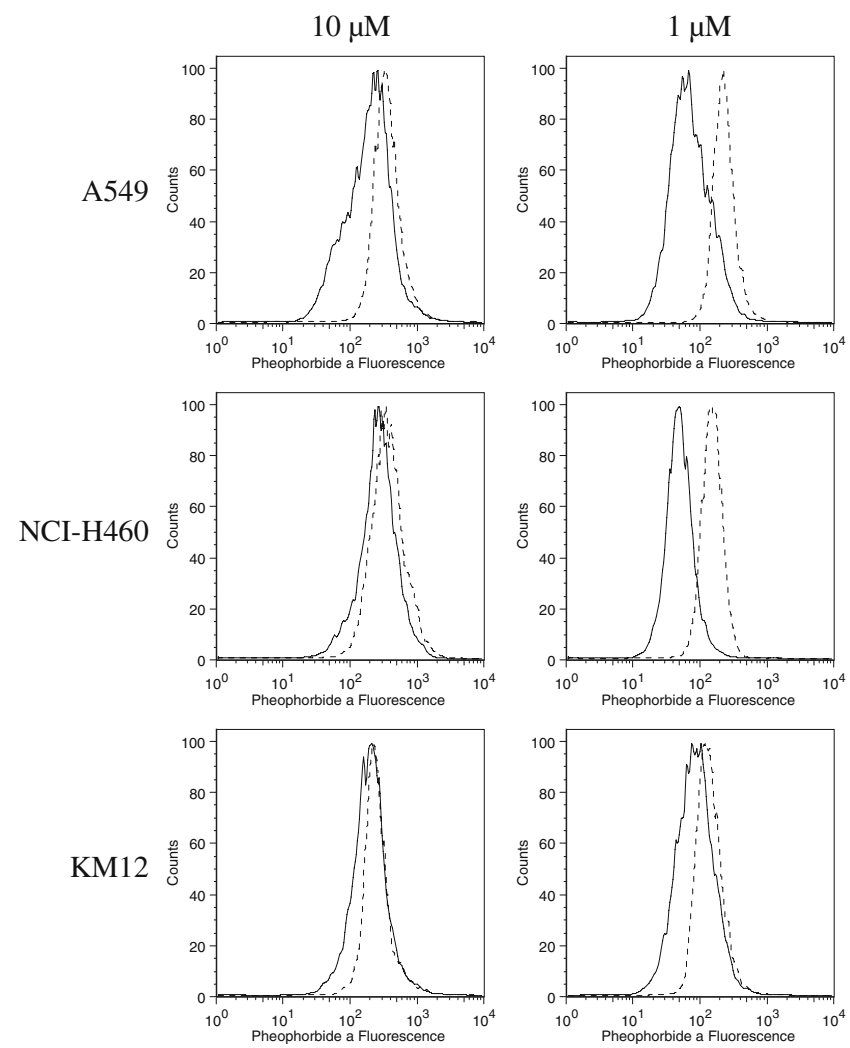

Fig. 2 Increasing sensitivity of the PhA flow assay. The A549, NCIH460 and KM12 cell lines which are known to express low but detectable levels of ABCG2 were incubated with $1 \mu \mathrm{M}$ (left column) or $10 \mu \mathrm{M}$ (right column) $\mathrm{PhA}$ in the presence of absence of $10 \mu \mathrm{M}$ FTC, for $30 \mathrm{~min}$. Cells were then washed then allowed to incubate for $1 \mathrm{~h}$ in PhA-free medium continuing with (dashed line) or without (solid line) FTC. ABCG2 expression, denoted by the difference between the solid and dashed histograms, is more readily detected when cells are incubated with $1 \mu \mathrm{M} \mathrm{PhA}$ 
studying ABCG2 function in clinical samples where multiple drug transporters may be expressed.

When determining ABCG2 function in clinical samples, we recommend that cells be incubated with pheophorbide a in the presence or absence of an ABCG2 inhibitor such as FTC for an initial 30 min period. Subsequently, cells should be washed and allowed to incubate for an additional hour in pheophorbide-free medium continuing with FTC to obtain the mean value of the FTC/Efflux histogram, or without FTC to obtain the mean value of the Efflux histogram [107]. Results can be presented as the difference in channel number between the Efflux and FTC/Efflux histograms or the Kolmogorov-Smirnov D value can be reported. In this way, one can assess the ability of the protein to prevent $\mathrm{PhA}$ accumulation, as well as the ability to extrude intracellular $\mathrm{PhA}$. This becomes especially important when examining cells that express low levels of ABCG2. As shown in Fig. 2, using PhA at a concentration of $1 \mu \mathrm{M}$ allows for greater sensitivity in detecting the low ABCG2 levels in MCF-7, A549, and H460 cells compared to using $\mathrm{PhA}$ at a concentration of $10 \mu \mathrm{M}$. Use of several low-level ABCG2-expressing cell lines is recommended, with MCF-7 included as a minimum.

Relatively few antibodies exist for detection of ABCG2 protein by flow cytometry. Minderman and colleagues have developed methodologies to detect ABCG2 by flow cytometry using the BXP-21 or BXP-34 antibodies [163] and the 5D3 antibody has been used extensively in flow cytometrybased assays [90, 163, 166]. Recent studies have shown that the binding of 5D3 is sensitive to conformational changes of the $\mathrm{ABCG} 2$ protein, with $5 \mathrm{D} 3$ binding being highest in the presence of the ABCG2 inhibitor Ko143 [166]. Compounds that decreased the ATPase activity of ABCG2 were found to increase 5D3 binding [166], much like what has been reported for the UIC2 antibody that recognizes Pgp [167]. Results with the 5D3 antibody, therefore, may not be entirely accurate unless conditions are carefully controlled. Again, low level controls must be included in the analysis and multiple antibodies should be used when possible. Similar to functional assays, results can be quantitated as the difference in channel number between the negative control histogram and ABCG2 antibody histograms or the Kolmogorov-Smirnov D value.

Clearly, sensitivity issues exist among the antibodies used to measure ABCG2 expression by flow cytometry. This is exemplified in the findings of Suvannasankha et al, where ABCG2 expression was measured in pretreatment blasts from 30 adult ALL patients [135]. Expression was determined by PCR analysis, immunophenotyping with the 5D3, BXP-21 or BXP-34 antibodies, or by functional assay using mitoxantrone as the substrate. While ABCG2 expression measured by the BXP-21 antibody correlated with expression measured by the BXP-34 or 5D3 antibody, expression measured by the BXP-34 antibody did not correlate with expression measured by 5D3 antibody, nor did antibody staining correlate with gene expression [135].

In contrast, van der Kolk et al reported a good correlation between $\mathrm{ABCG} 2$ expression measured with $\mathrm{BXP}-21$ or BXP-34 and ABCG2 function assayed with mitoxantrone [130], suggesting that differing methodologies, as well as antibody sensitivities, may be the cause of discordant results reported in patient samples. Development of sensitive and specific antibodies to detect ABCG2 by flow cytometry as well as use of consistent methodologies will be crucial to determining ABCG2 expression in clinical samples which usually express low levels. Additionally, as the BXP-34 and BXP-21 antibodies require cell permeabilization, these antibodies will most likely recognize intracellular $\mathrm{ABCG} 2$ and it is not yet clear what the relationship of total intracellular ABCG2 expression is to drug transport capacity.

\section{Conclusion}

The challenges of translating ABCG2 into a target for future clinical trials are daunting. Given the lack of success of phase II and III trials with Pgp inhibitors [168], one may argue that we still have not successfully translated Pgp into a clinical target. With regard to ABCG2, we do not yet know what cancers express ABCG2 as a mechanism of resistance, we have not developed potent, selective inhibitors to target $\mathrm{ABCG} 2$ and we have no surrogate assay to test for ABCG2 inhibition in vivo. However, if we make a concerted effort now to avoid the mistakes made with Pgp and instead develop sensitive, reproducible methods for assessing ABCG2 expression in clinical samples, we will be able to develop effective clinical trials aimed at overcoming ABCG2-mediated drug resistance.

Acknowledgements This research was supported by the Intramural Research Program of the NIH, National Cancer Institute, Center for Cancer Research and the Commissioned Corps of the Public Health Service.

\section{References}

1. Gottesman, M. M., Fojo, T., \& Bates, S. E. (2002). Multidrug resistance in cancer: Role of ATP-dependent transporters. Nature Reviews Cancer, 2, 48-58.

2. Roninson, I. B., Chin, J. E., Choi, K., Gros, P., Housman, D. E., Fojo, A., et al. (1986). Isolation of human mdr DNA sequences amplified in multidrug-resistant KB carcinoma cells. Proceedings of the National Academy of Sciences of the United States of America, 83, 4538-4542.

3. Shen, D. W., Fojo, A., Chin, J. E., Roninson, I. B., Richert, N., Pastan, I., et al. (1986). Human multidrug-resistant cell lines: 
Increased mdr-1 expression can precede gene amplification. Science, 232, 643-645.

4. Leonard, G. D., Fojo, T., \& Bates, S. E. (2003). The role of ABC transporters in clinical practice. Oncologist, 8, 411-424.

5. Cole, S. P. C., Bhardwaj, G., Gerlach, J. H., Mackie, J. E., Grant, C. E., Almquist, K. C., et al. (1993). Overexpression of a transporter gene in a multidrug-resistant human lung cancer cell line. Science, 258, 1650-1654.

6. Kruh, G. D., Zeng, H., Rea, P. A., Liu, G., Chen, Z. S., Lee, K., et al. (2001). MRP subfamily transporters and resistance to anticancer agents. Journal of Bioenergetics and Biomembranes, 33, 493-501.

7. Hipfner, D. R., Deeley, R. G., \& Cole, S. P. (1999). Structural, mechanistic and clinical aspects of MRP1. Biochimica et Biophysica Acta, 1461, 359-376.

8. Taylor, C. W., Dalton, W. S., Parrish, P. R., Gleason, M. C., Bellamy, W. T., Thompson, F. H., et al. (1991). Different mechanisms of decreased drug accumulation in doxorubicin and mitoxantrone resistant variants of the MCF7 human breast cancer cell line. British Journal of Cancer, 63, 923-929.

9. Dietel, M., Arps, H., Lage, H., \& Niendorf, A. (1990). Membrane vesicle formation due to acquired mitoxantrone resistance in human gastric carcinoma cell line EPG85-257. Cancer Research, 50, 6100-6106.

10. Nakagawa, M., Schneider, E., Dixon, K. H., Horton, J., Kelley, K., Morrow, C., et al. (1992). Reduced intracellular drug accumulation in the absence of P-glycoprotein $(m d r 1)$ overexpression in mitoxantrone-resistant human MCF-7 human breast cancer cells. Cancer Research, 52, 6175-6181.

11. Kellner, U., Hutchinson, L., Seidel, A., Lage, H., Danks, M. K., Dietel, M., et al. (1997). Decreased drug accumulation in a mitoxantrone-resistant gastric carcinoma cell line in the absence of P-glycoprotein. International Journal of Cancer, 71, 817-824.

12. Futscher, B. W., Abbaszadegan, M. R., Doman, F., \& Dalton, W. S. (1994). Analysis of MRP mRNA in mitoxantroneselected, multidrug resistant human tumor cells. Biochemical Pharmacology, 47, 1601-1606.

13. Yang, C. J., Horton, J. K., Cowan, K. H., \& Schneider, E. (1995). Cross-resistance to camptothecin analogues in a mitoxantrone-resistant human breast carcinoma cell line is not due to DNA topoisomerase I alterations. Cancer Research, $55,4004-4009$.

14. Chen, Y.-N., Mickley, L. A., Schwartz, A. M., Acton, E. M., Hwang, J., \& Fojo, A. T. (1990). Characterization of Adriamycin-resistant human breast cancer cells which display overexpression of a novel resistance-related membrane protein. Journal of Biological Chemistry, 265, 10073-10080.

15. Doyle, L. A., Yang, W., Abruzzo, L. V., Krogmann, T., Gao, Y., Rishi, A. K., et al. (1998). A multidrug resistance transporter from human MCF-7 breast cancer cells. Proceedings of the National Academy of Sciences of the United States of America, 95, 15665-15670.

16. Allikmets, R., Schriml, L. M., Hutchinson, A., Romano-Spica, V., \& Dean, M. (1998). A human placenta-specific ATP-binding cassette gene (ABCP) on chromosome $4 \mathrm{q} 22$ that is involved in multidrug resistance. Cancer Research, 58, 5337-5339.

17. Miyake, K., Mickley, L., Litman, T., Zhan, Z., Robey, R., Cristensen, B., et al. (1999). Molecular cloning of cDNAs which are highly overexpressed in mitoxantrone-resistant cells: Demonstration of homology to $\mathrm{ABC}$ transport genes. Cancer Research, 59, 8-13.

18. Dean, M., Rzhetsky, A., \& Allikmets, R. (2001). The human ATP-binding cassette (ABC) transporter superfamily. Genome Research, 11, 1156-1166.

19. Wang, N., Lan, D., Chen, W., Matsuura, F., \& Tall, A. R. (2004). ATP-binding cassette transporters G1 and G4 mediate cellular cholesterol efflux to high-density lipoproteins. Proceedings of the National Academy of Sciences of the United States of America, 101, 9774-9779.

20. Mickley, L., Jain, P., Miyake, K., Schriml, L. M., Rao, K., Fojo, T., et al. (2001). An ATP-binding cassette gene (ABCG3) closely related to the multidrug transporter $\mathrm{ABCG} 2$ (MXR/ABCP) has an unusual ATP-binding domain. Mammalian Genome, 12, 86-88.

21. Yu, L., Li-Hawkins, J., Hammer, R. E., Berge, K. E., Horton, J. D., Cohen, J. C., et al. (2002). Overexpression of ABCG5 and ABCG8 promotes biliary cholesterol secretion and reduces fractional absorption of dietary cholesterol. Journal of Clinical Investigation, 110, 671-680.

22. Bailey-Dell, K. J., Hassel, B., Doyle, L. A., \& Ross, D. D. (2001). Promoter characterization and genomic organization of the human breast cancer resistance protein (ATP-binding cassette transporter G2) gene. Biochimica et Biophysica Acta, 1520, 234-241.

23. Knutsen, T., Rao, V. K., Ried, T., Mickley, L., Schneider, E., Miyake, K., et al. (2000). Amplification of 4q21-q22 and the MXR gene in independently derived mitoxantrone-resistant cell lines. Genes Chromosomes \& Cancer, 27, 110-116.

24. Ee, P. L., Kamalakaran, S., Tonetti, D., He, X., Ross, D. D., \& Beck, W. T. (2004). Identification of a novel estrogen response element in the breast cancer resistance protein (ABCG2) gene. Cancer Research, 64, 1247-1251.

25. Imai, Y., Ishikawa, E., Asada, S., \& Sugimoto, Y. (2005). Estrogen-mediated post transcriptional down-regulation of breast cancer resistance protein/ABCG2. Cancer Research, 65, 596604.

26. Wang, H., Zhou, L., Gupta, A., Vethanayagam, R. R., Zhang, Y., Unadkat, J. D., et al. (2006). Regulation of BCRP/ABCG2 expression by progesterone and 17 \{beta\}-estradiol in human placental BeWo cells. American Journal of Physiology: Endocrinology and Metabolism, 290(5), 798-807.

27. Yasuda, S., Itagaki, S., Hirano, T., \& Iseki, K. (2005). Expression level of ABCG2 in the placenta decreases from the mid stage to the end of gestation. Bioscience, Biotechnology, and Biochemistry, 69, 1871-1876.

28. Jonker, J. W., Merino, G., Musters, S., van Herwaarden, A. E., Bolscher, E., Wagenaar, E., et al. (2005). The breast cancer resistance protein BCRP (ABCG2) concentrates drugs and carcinogenic xenotoxins into milk. Nature Medicine, 11, 127-129.

29. Krishnamurthy, P., Ross, D. D., Nakanishi, T., Bailey-Dell, K., Zhou, S., Mercer, K. E., et al. (2004). The stem cell marker Bcrp/ABCG2 enhances hypoxic cell survival through interactions with heme. Journal of Biological Chemistry, 279, $24218-24225$.

30. To, K. K., Zhan, Z., \& Bates, S. E. (2006). Aberrant promoter methylation of the ABCG2 gene in renal carcinoma. Molecular and Cellular Biology, 26, 8572-8585.

31. Turner, J. G., Gump, J. L., Zhang, C., Cook, J. M., Marchion, D., Hazlehurst, L., et al. (2006). ABCG2 expression, function and promoter methylation in human multiple myeloma. Blood, 108 (12), 3881-3889.

32. Maliepaard, M., Scheffer, G. L., Faneyte, I. F., van Gastelen, M. A., Pijnenborg, A. C., Schinkel, A. H., et al. (2001). Subcellular localization and distribution of the breast cancer resistance protein transporter in normal human tissues. Cancer Research, $61,3458-3464$.

33. Litman, T., Jensen, U., Hansen, A., Covitz, K., Zhan, Z., Fetsch, P., et al. (2002). Use of peptide antibodies to probe for the mitoxantrone resistance-associated protein $\mathrm{MXR} / \mathrm{BCRP} / \mathrm{ABCP} /$ ABCG2. Biochimica et Biophysica Acta, 1565, 6-16.

34. Fetsch, P. A., Abati, A., Litman, T., Morisaki, K., Honjo, Y., Mittal, K., et al. (2005). Localization of the ABCG2 mitoxan- 
trone resistance-associated protein in normal tissues. Cancer Letter, 235(1), 84-92.

35. Jonker, J. W., Smit, J. W., Brinkhuis, R. F., Maliepaard, M., Beijnen, J. H., Schellens, J. H., et al. (2000). Role of breast cancer resistance protein in the bioavailability and fetal penetration of topotecan. Journal of the National Cancer Institute, 92, $1651-1656$.

36. Staud, F., Vackova, Z., Pospechova, K., Pavek, P., Ceckova, M., Libra, A., et al. (2006). Expression and transport activity of breast cancer resistance protein (Bcrp/Abcg2) in dually perfused rat placenta and HRP-1 cell line. Journal of Pharmacology and Experimental Therapeutics, 319, 53-62.

37. van Herwaarden, A. E., Wagenaar, E., Karnekamp, B., Merino, G., Jonker, J. W., \& Schinkel, A. H. (2006). Breast cancer resistance protein (Bcrp1/Abcg2) reduces systemic exposure of the dietary carcinogens aflatoxin B1, IQ and Trp-P-1 but also mediates their secretion into breast milk. Carcinogenesis, 27, $123-130$.

38. Merino, G., Jonker, J. W., Wagenaar, E., van Herwaarden, A. E., \& Schinkel, A. H. (2005). The breast cancer resistance protein (BCRP/ABCG2) affects pharmacokinetics, hepatobiliary excretion, and milk secretion of the antibiotic nitrofurantoin. Molecular Pharmacology, 67, 1758-1764.

39. Bart, J., Hollema, H., Groen, H. J., de Vries, E. G., Hendrikse, N. H., Sleijfer, D. T., et al. (2004). The distribution of drug-efflux pumps, P-gp, BCRP, MRP1 and MRP2, in the normal bloodtestis barrier and in primary testicular tumours. European Journal of Cancer, 40, 2064-2070.

40. Lassalle, B., Bastos, H., Louis, J. P., Riou, L., Testart, J., Dutrillaux, B., et al. (2004). 'Side Population' cells in adult mouse testis express Bcrp1 gene and are enriched in spermatogonia and germinal stem cells. Development, 131, 479-487.

41. Cooray, H. C., Blackmore, C. G., Maskell, L., \& Barrand, M. A. (2002). Localisation of breast cancer resistance protein in microvessel endothelium of human brain. Neuroreport, 13, 2059-2063.

42. Zhang, W., Mojsilovic-Petrovic, J., Andrade, M. F., Zhang, H., Ball, M., \& Stanimirovic, D. B. (2003). The expression and functional characterization of ABCG2 in brain endothelial cells and vessels. FASEB Journal, 17, 2085-2087.

43. Cisternino, S., Mercier, C., Bourasset, F., Roux, F., \& Scherrmann, J. M. (2004). Expression, up-regulation, and transport activity of the multidrug-resistance protein Abcg2 at the mouse blood-brain barrier. Cancer Research, 64, 3296-3301.

44. Breedveld, P., Pluim, D., Cipriani, G., Wielinga, P., van Tellingen, O., Schinkel, A. H., et al. (2005). The effect of Bcrp1 (Abcg2) on the in vivo pharmacokinetics and brain penetration of imatinib mesylate (Gleevec): Implications for the use of breast cancer resistance protein and P-glycoprotein inhibitors to enable the brain penetration of imatinib in patients. Cancer Research, $65,2577-2582$.

45. Loscher, W., \& Potschka, H. (2005). Drug resistance in brain diseases and the role of drug efflux transporters. Nature Reviews. Neuroscience, 6, 591-602.

46. Kruijtzer, C. M., Beijnen, J. H., Rosing, H., Ten Bokkel Huinink, W. W., Schot, M., Jewell, R. C., et al. (2002). Increased oral bioavailability of topotecan in combination with the breast cancer resistance protein and P-glycoprotein inhibitor GF120918. Journal of Clinical Oncology, 20, 2943-2950.

47. Stewart, C. F., Leggas, M., Schuetz, J. D., Panetta, J. C., Cheshire, P. J., Peterson, J., et al. (2004). Gefitinib enhances the antitumor activity and oral bioavailability of irinotecan in mice. Cancer Research, 64, 7491-7499.

48. van Herwaarden, A. E., Jonker, J. W., Wagenaar, E., Brinkhuis, R. F., Schellens, J. H., Beijnen, J. H., et al. (2003). The breast cancer resistance protein (Bcrp1/Abcg2) restricts exposure to the dietary carcinogen 2-amino-1-methyl-6-phenylimidazo[4,5-b] pyridine. Cancer Research, 63, 6447-6452.

49. Kuppens, I. E., Breedveld, P., Beijnen, J. H., \& Schellens, J. H. (2005). Modulation of oral drug bioavailability: From preclinical mechanism to therapeutic application. Cancer Investigation, 23, 443-464.

50. Schellens, J. H., Malingre, M. M., Kruijtzer, C. M., Bardelmeijer, H. A., van Tellingen, O., Schinkel, A. H., et al. (2000). Modulation of oral bioavailability of anticancer drugs: From mouse to man. European Journal of Pharmaceutical Sciences, $12,103-110$.

51. Choudhuri, S., \& Klaassen, C. D. (2006). Structure, function, expression, genomic organization, and single nucleotide polymorphisms of human ABCB1 (MDR1), ABCC (MRP), and ABCG2 (BCRP) efflux transporters. International Journal of Toxicology, 25, 231-259.

52. Goodell, M. A., Brose, K., Paradis, G., Conner, A. S., \& Mulligan, R. C. (1996). Isolation and functional properties of murine hematopoietic stem cells that are replicating in vivo. Journal of Experimental Medicine, 183, 1797-1806.

53. Zhou, S., Schuetz, J. D., Bunting, K. D., Colapietro, A. M., Sampath, J., Morris, J. J., et al. (2001). The ABC transporter Bcrp1/ABCG2 is expressed in a wide variety of stem cells and is a molecular determinant of the side-population phenotype. Nature Medicine, 7, 1028-1034.

54. Scharenberg, C. W., Harkey, M. A., \& Torok-Storb, B. (2002). The ABCG2 transporter is an efficient Hoechst 33342 efflux pump and is preferentially expressed by immature human hematopoietic progenitors. Blood, 99, 507-512.

55. Lown, K. S., Kolars, J. C., Thummel, K. E., Barnett, J. L., Kunze, K. L., Wrighton, S. A., et al. (1994). Interpatient heterogeneity in expression of CYP3A4 and CYP3A5 in small bowel. Lack of prediction by the erythromycin breath test. Drug Metabolism and Disposition, 22, 947-955.

56. Zhou, S., Morris, J. J., Barnes, Y., Lan, L., Schuetz, J. D., \& Sorrentino, B. P. (2002). Bcrp1 gene expression is required for normal numbers of side population stem cells in mice, and confers relative protection to mitoxantrone in hematopoietic cells in vivo. Proceedings of the National Academy of Sciences of the United States of America, 99, 12339-12344.

57. Lechner, A., Leech, C. A., Abraham, E. J., Nolan, A. L., \& Habener, J. F. (2002). Nestin-positive progenitor cells derived from adult human pancreatic islets of Langerhans contain side population (SP) cells defined by expression of the ABCG2 (BCRP1) ATP-binding cassette transporter. Biochemical and Biophysical Research Communications, 293, 670-674.

58. Alvi, A. J., Clayton, H., Joshi, C., Enver, T., Ashworth, A., Vivanco, M. M., et al. (2003). Functional and molecular characterisation of mammary side population cells. Breast Cancer Research, 5, R1-R8.

59. Summer, R., Kotton, D. N., Sun, X., Ma, B., Fitzsimmons, K., \& Fine, A. (2003). Side population cells and Bcrp1 expression in lung. American Journal of Physiology. Lung Cellular and Molecular Physiology, 285, L97-L104.

60. Budak, M. T., Alpdogan, O. S., Zhou, M., Lavker, R. M., Akinci, M. A., \& Wolosin, J. M. (2005). Ocular surface epithelia contain ABCG2-dependent side population cells exhibiting features associated with stem cells. Journal of Cell Science, 118, 1715-1724.

61. Du, Y., Funderburgh, M. L., Mann, M. M., SundarRaj, N., \& Funderburgh, J. L. (2005). Multipotent stem cells in human corneal stroma. Stem Cells, 23, 1266-1275.

62. Kondo, T., Setoguchi, T., \& Taga, T. (2004). Persistence of a small subpopulation of cancer stem-like cells in the C6 glioma 
cell line. Proceedings of the National Academy of Sciences of the United States of America, 101, 781-786.

63. Hirschmann-Jax, C., Foster, A. E., Wulf, G. G., Nuchtern, J. G., Jax, T. W., Gobel, U., et al. (2004). A distinct "side population" of cells with high drug efflux capacity in human tumor cells. Proceedings of the National Academy of Sciences of the United States of America, 101, 14228-14233.

64. Seigel, G. M., Campbell, L. M., Narayan, M., \& GonzalezFernandez, F. (2005). Cancer stem cell characteristics in retinoblastoma. Molecular Vision, 11, 729-737.

65. Haraguchi, N., Utsunomiya, T., Inoue, H., Tanaka, F., Mimori, K., Barnard, G. F., et al. (2005). Characterization of a Side population of cancer cells from human gastrointestinal system. Stem Cells, 24(3), 506-513.

66. Doyle, L. A., \& Ross, D. D. (2003). Multidrug resistance mediated by the breast cancer resistance protein BCRP (ABCG2). Oncogene, 22, 7340-7358.

67. Bates, S. E., Robey, R., Miyake, K., Rao, K., Ross, D. D., \& Litman, T. (2001). The role of half-transporters in multidrug resistance. Journal of Bioenergetics and Biomembranes, 33, 503-511.

68. Ross, D. D., Yang, W., Abruzzo, L. V., Dalton, W. S., Schneider, E., Lage, H., et al. (1999). Atypical multidrug resistance: Breast cancer resistance protein messenger RNA expression in mitoxantrone-selected cell lines. Journal of the National Cancer Institute, 91, 429-433.

69. Ma, J., Maliepaard, M., Nooter, K., Loos, W. J., Kolker, H. J., Verweij, J., et al. (1998). Reduced cellular accumulation of topotecan: A novel mechanism of resistance in a human ovarian cancer cell line. British Journal of Cancer, 77, $1645-1652$.

70. Maliepaard, M., van Gastelen, M. A., de Jong, L. A., Pluim, D., van Waardenburg, R. C., Ruevekamp-Helmers, M. C., et al. (1999). Overexpression of the BCRP/MXR/ABCP gene in a topotecan-selected ovarian tumor cell line. Cancer Research, $59,4559-4563$.

71. Kawabata, S., Oka, M., Shiozawa, K., Tsukamoto, K., Nakatomi, K., Soda, H., et al. (2001). Breast cancer resistance protein directly confers SN-38 resistance of lung cancer cells. Biochemical and Biophysical Research Communications, 280, 1216-1223.

72. Robey, R. W., Medina-Perez, W. Y., Nishiyama, K., Lahusen, T., Miyake, K., Litman, T., et al. (2001). Overexpression of the ATP-binding cassette half-transporter, ABCG2 (MXR/BCRP/ $\mathrm{ABCP} 1$ ), in flavopiridol-resistant human breast cancer cells. Clinical Cancer Research, 7, 145-152.

73. van Hattum, A. H., Hoogsteen, I. J., Schluper, H. M., Maliepaard, M., Scheffer, G. L., Scheper, R. J., et al. (2002). Induction of breast cancer resistance protein by the camptothecin derivative DX-8951f is associated with minor reduction of antitumour activity. British Journal of Cancer, 87, 665-672.

74. Van Hattum, A. H., Schluper, H. M., Hausheer, F. H., Pinedo, H. M., \& Boven, E. (2002). Novel camptothecin derivative BNP1350 in experimental human ovarian cancer: Determination of efficacy and possible mechanisms of resistance. International Journal of Cancer, 100, 22-29.

75. Komatani, H., Kotani, H., Hara, Y., Nakagawa, R., Matsumoto, M., Arakawa, H., et al. (2001). Identification of breast cancer resistant protein/mitoxantrone resistance/placenta-specific, ATPbinding cassette transporter as a transporter of NB-506 and J107088, topoisomerase I inhibitors with an indolocarbazole structure. Cancer Research, 61, 2827-2832.

76. Erlichman, C., Boerner, S. A., Hallgren, C. G., Spieker, R., Wang, X. Y., James, C. D., et al. (2001). The HER tyrosine kinase inhibitor CI1033 enhances cytotoxicity of 7-ethyl-10hydroxycamptothecin and topotecan by inhibiting breast cancer resistance protein-mediated drug efflux. Cancer Research, 61, 739-748.

77. Elkind, N. B., Szentpetery, Z., Apati, A., Ozvegy-Laczka, C., Varady, G., Ujhelly, O., et al. (2005). Multidrug transporter ABCG2 prevents tumor cell death induced by the epidermal growth factor receptor inhibitor Iressa (ZD1839, Gefitinib). Cancer Research, 65, 1770-1777.

78. Burger, H., van Tol, H., Boersma, A. W., Brok, M., Wiemer, E. A., Stoter, G., et al. (2004). Imatinib mesylate (STI571) is a substrate for the breast cancer resistance protein (BCRP)/ ABCG2 drug pump. Blood, 104, 2940-2942.

79. Chen, Z. S., Robey, R. W., Belinsky, M. G., Shchaveleva, I., Ren, X. Q., Sugimoto, Y., et al. (2003). Transport of methotrexate, methotrexate polyglutamates, and 17beta-estradiol 17-(beta-D-glucuronide) by ABCG2: Effects of acquired mutations at R482 on methotrexate transport. Cancer Research, 63, 4048-4054.

80. Volk, E. L., \& Schneider, E. (2003). Wild-type breast cancer resistance protein (BCRP/ABCG2) is a methotrexate polyglutamate transporter. Cancer Research, 63, 5538-5543.

81. Shafran, A., Ifergan, I., Bram, E., Jansen, G., Kathmann, I., Peters, G. J., et al. (2005). ABCG2 harboring the Gly482 mutation confers high-level resistance to various hydrophilic antifolates. Cancer Research, 65, 8414-8422.

82. Lee, J. S., Scala, S., Matsumoto, Y., Dickstein, B., Robey, R., Zhan, Z., et al. (1997). Reduced drug accumulation and multidrug resistance in human breast cancer cells without associated P-glycoprotein or MRP overexpression. Journal of Cellular Biochemistry, 65, 513-526.

83. Rabindran, S. K., He, H., Singh, M., Brown, E., Collins, K. I., Annable, T., et al. (1998). Reversal of a novel multidrug resistance mechanism in human colon carcinoma cells by fumitremorgin C. Cancer Research, 58, 5850-5858.

84. Robey, R. W., Honjo, Y., van de Laar, A., Miyake, K., Regis, J. T., Litman, T., et al. (2001). A functional assay for detection of the mitoxantrone resistance protein, MXR (ABCG2). Biochimica et Biophysica Acta, 1512, 171-182.

85. Honjo, Y., Hrycyna, C. A., Yan, Q. W., Medina-Perez, W. Y., Robey, R. W., van de Laar, A., et al. (2001). Acquired mutations in the MXR/ $\mathrm{BCRP} / \mathrm{ABCP}$ gene alter substrate specificity in MXR/BCRP/ABCPoverexpressing cells. Cancer Research, 61, 6635-6639.

86. Allen, J. D., Jackson, S. C., \& Schinkel, A. H. (2002). A mutation hot spot in the Bcrp1 (Abcg2) multidrug transporter in mouse cell lines selected for Doxorubicin resistance. Cancer Research, 62, 2294-2299.

87. Ozvegy-Laczka, C., Koblos, G., Sarkadi, B., \& Varadi, A. (2005). Single amino acid (482) variants of the ABCG2 multidrug transporter: Major differences in transport capacity and substrate recognition. Biochimica et Biophysica Acta, 1668, 53-63.

88. Ejendal, K. F., Diop, N. K., Schweiger, L. C., \& Hrycyna, C. A. (2006). The nature of amino acid 482 of human ABCG2 affects substrate transport and ATP hydrolysis but not substrate binding. Protein Science, 15, 1597-1607.

89. Miwa, M., Tsukahara, S., Ishikawa, E., Asada, S., Imai, Y., \& Sugimoto, Y. (2003). Single amino acid substitutions in the transmembrane domains of breast cancer resistance protein (BCRP) alter cross resistance patterns in transfectants. International Journal of Cancer, 107, 757-763.

90. Robey, R. W., Honjo, Y., Morisaki, K., Nadjem, T. A., Runge, S., Risbood, M., et al. (2003). Mutations at amino acid 482 in the ABCG2 gene affect substrate and antagonist specificity. British Journal of Cancer, 89, 1971-1978.

91. Minderman, H., O’Loughlin, K. L., Pendyala, L., \& Baer, M. R. (2004). VX-710 (biricodar) increases drug retention and enhances chemosensitivity in resistant cells overexpressing P-glyco- 
protein, multidrug resistance protein, and breast cancer resistance protein. Clinical Cancer Research, 10, 1826-1834.

92. Huang, L., Wang, Y., \& Grimm, S. W. (2006). ATP-dependent transport of rosuvastatin in membrane vesicles expressing breast cancer resistant protein. Drug Metabolism and Disposition, 34 (5), 738-742.

93. Fujino, H., Saito, T., Ogawa, S., \& Kojima, J. (2005). Transporter-mediated influx and efflux mechanisms of pitavastatin, a new inhibitor of HMG-CoA reductase. Journal of Pharmacy and Pharmacology, 57, 1305-1311.

94. Hirano, M., Maeda, K., Matsushima, S., Nozaki, Y., Kusuhara, H., \& Sugiyama, Y. (2005). Involvement of BCRP (ABCG2) in the biliary excretion of pitavastatin. Molecular Pharmacology, $68,800-807$.

95. Matsushima, S., Maeda, K., Kondo, C., Hirano, M., Sasaki, M., Suzuki, H., et al. (2005). Identification of the hepatic efflux transporters of organic anions using double-transfected MadinDarby canine kidney II cells expressing human organic aniontransporting polypeptide 1B1 (OATP1B1)/multidrug resistanceassociated protein 2 , OATP1B1/multidrug resistance 1 , and OATP1B1/breast cancer resistance protein. Journal of Pharmacology and Experimental Therapeutics, 314, 1059-1067.

96. Imai, Y., Tsukahara, S., Asada, S., \& Sugimoto, Y. (2004). Phytoestrogens/flavonoids reverse breast cancer resistance protein/ABCG2-mediated multidrug resistance. Cancer Research, 64, 4346-4352.

97. Sesink, A. L., Arts, I. C., de Boer, V. C., Breedveld, P., Schellens, J. H., Hollman, P. C., et al. (2005). Breast cancer resistance protein (Bcrp1/Abcg2) limits net intestinal uptake of quercetin in rats by facilitating apical efflux of glucuronides. Molecular Pharmacology, 67, 1999-2006.

98. Youdim, K. A., Qaiser, M. Z., Begley, D. J., Rice-Evans, C. A., \& Abbott, N. J. (2004). Flavonoid permeability across an in situ model of the blood-brain barrier. Free Radical Biology \& Medicine, 36, 592-604.

99. Merino, G., Alvarez, A. I., Pulido, M. M., Molina, A. J., Schinkel, A. H., \& Prieto, J. G. (2006). Breast Cancer Resistance Protein (BCRP/ABCG2) transports fluoroquinolone antibiotics and affects their oral availability, pharmacokinetics and milk secretion. Drug Metabolism and Disposition, 34(4), 690-695.

100. Janvilisri, T., Shahi, S., Venter, H., Balakrishnan, L., \& van Veen, H. W. (2005). Arginine-482 is not essential for transport of antibiotics, primary bile acids and unconjugated sterols by the human breast cancer resistance protein (ABCG2). Biochemical Journal, 385, 419-426.

101. Merino, G., Jonker, J. W., Wagenaar, E., Pulido, M. M., Molina, A. J., Alvarez, A. I., et al. (2005). Transport of anthelmintic benzimidazole drugs by breast cancer resistance protein (BCRP/ ABCG2). Drug Metabolism and Disposition, 33, 614-618.

102. Rabindran, S. K., Ross, D. D., Doyle, L. A., Yang, W., \& Greenberger, L. M. (2000). Fumitremorgin C reverses multidrug resistance in cells transfected with the breast cancer resistance protein. Cancer Research, 60, 47-50.

103. Allen, J. D., van Loevezijn, A., Lakhai, J. M., van der Valk, M., van Tellingen, O., Reid, G., et al. (2002). Potent and specific inhibition of the breast cancer resistance protein multidrug transporter in vitro and in mouse intestine by a novel analogue of fumitremorgin C. Molecular Cancer Therapeutics, 1, 417-425.

104. van Loevezijn, A., Allen, J. D., Schinkel, A. H., \& Koomen, G. J. (2001). Inhibition of BCRP-mediated drug efflux by fumitremorgin-type indolyl diketopiperazines. Bioorganic \& Medicinal Chemistry Letters, 11, 29-32.

105. Woehlecke, H., Osada, H., Herrmann, A., \& Lage, H. (2003). Reversal of breast cancer resistance protein-mediated drug resistance by tryprostatin A. International Journal of Cancer, 107, 721-728.
106. de Bruin, M., Miyake, K., Litman, T., Robey, R., \& Bates, S. E. (1999). Reversal of resistance by GF120918 in cell lines expressing the ABC half-transporter, MXR. Cancer Letter, 146, 117-126.

107. Robey, R. W., Steadman, K., Polgar, O., Morisaki, K., Blayney, M., Mistry, P., et al. (2004). Pheophorbide a is a specific probe for ABCG2 function and inhibition. Cancer Research, 64, 1242-1246.

108. Yang, C. H., Chen, Y. C., \& Kuo, M. L. (2003). Novobiocin sensitizes BCRP/MXR/ABCP overexpressing topotecan-resistant human breast carcinoma cells to topotecan and mitoxantrone. Anticancer Research, 23, 2519-2523.

109. Shiozawa, K., Oka, M., Soda, H., Yoshikawa, M., Ikegami, Y., Tsurutani, J., et al. (2004). Reversal of breast cancer resistance protein (BCRP/ABCG2)-mediated drug resistance by novobiocin, a coumermycin antibiotic. International Journal of Cancer, 108, 146-151.

110. Yanase, K., Tsukahara, S., Asada, S., Ishikawa, E., Imai, Y., \& Sugimoto, Y. (2004). Gefitinib reverses breast cancer resistance protein-mediated drug resistance. Molecular Cancer Therapeutics, 3, 1119-1125.

111. Cooray, H. C., Janvilisri, T., van Veen, H. W., Hladky, S. B., \& Barrand, M. A. (2004). Interaction of the breast cancer resistance protein with plant polyphenols. Biochemical and Biophysical Research Communications, 317, 269-275.

112. Zhang, S., Wang, X., Sagawa, K., \& Morris, M. E. (2005). Flavonoids chrysin and benzoflavone, potent breast cancer resistance protein inhibitors, have no significant effect on topotecan pharmacokinetics in rats or mdrla/lb $(-/-)$ mice. Drug Metabolism and Disposition, 33, 341-348.

113. Zhang, S., Yang, X., \& Morris, M. E. (2004). Flavonoids are inhibitors of breast cancer resistance protein (ABCG2)-mediated transport. Molecular Pharmacology, 65, 1208-1216.

114. Zhang, S., Yang, X., Coburn, R. A., \& Morris, M. E. (2005). Structure activity relationships and quantitative structure activity relationships for the flavonoid-mediated inhibition of breast cancer resistance protein. Biochemical Pharmacology, 70, 627-639.

115. Ahmed-Belkacem, A., Pozza, A., Munoz-Martinez, F., Bates, S. E., Castanys, S., Gamarro, F., et al. (2005). Flavonoid structureactivity studies identify 6-prenylchrysin and tectochrysin as potent and specific inhibitors of breast cancer resistance protein ABCG2. Cancer Research, 65, 4852-4860.

116. Zhou, X. F., Yang, X., Wang, Q., Coburn, R. A., \& Morris, M. E. (2005). Effects of dihydropyridines and pyridines on multidrug resistance mediated by breast cancer resistance protein: In vitro and in vivo studies. Drug Metabolism and Disposition, 33, 1220-1228.

117. Shukla, S., Robey, R. W., Bates, S. E., \& Ambudkar, S. V. (2006). The calcium channel blockers, 1,4-dihydropyridines, are substrates of the multidrug resistance-linked ABC drug transporter, ABCG2. Biochemistry, 45, 8940-8951.

118. Cascorbi, I. (2006). Role of pharmacogenetics of ATP-binding cassette transporters in the pharmacokinetics of drugs. Pharmacology \& Therapeutics, 112(2), 457-473.

119. Imai, Y., Nakane, M., Kage, K., Tsukahara, S., Ishikawa, E., Tsuruo, T., et al. (2002). C421A polymorphism in the human breast cancer resistance protein gene is associated with low expression of $\mathrm{Q} 141 \mathrm{~K}$ protein and low-level drug resistance. Molecular Cancer Therapeutics, 1, 611-616.

120. Kondo, C., Suzuki, H., Itoda, M., Ozawa, S., Sawada, J., Kobayashi, D., et al. (2004). Functional analysis of SNPs variants of BCRP/ABCG2. Pharmaceutical Research, 21, 1895-1903.

121. Kobayashi, D., Ieiri, I., Hirota, T., Takane, H., Maegawa, S., Kigawa, J., et al. (2005). Functional assessment of ABCG2 (BCRP) gene polymorphisms to protein expression in human placenta. Drug Metabolism and Disposition, 33, 94-101.

122. Morisaki, K., Robey, R. W., Ozvegy-Laczka, C., Honjo, Y., Polgar, O., Steadman, K., et al. (2005). Single nucleotide 
polymorphisms modify the transporter activity of ABCG2. Cancer Chemotherapy and Pharmacology, 56, 161-172.

123. Mizuarai, S., Aozasa, N., \& Kotani, H. (2004). Single nucleotide polymorphisms result in impaired membrane localization and reduced atpase activity in multidrug transporter ABCG2. International Journal of Cancer, 109, 238-246.

124. de Jong, F. A., Marsh, S., Mathijssen, R. H., King, C., Verweij, J., Sparreboom, A., et al. (2004). ABCG2 pharmacogenetics: Ethnic differences in allele frequency and assessment of influence on irinotecan disposition. Clinical Cancer Research, 10, 5889-5894.

125. Sparreboom, A., Loos, W. J., Burger, H., Sissung, T. M., Verweij, J., Figg, W. D., et al. (2005). Effect of ABCG2 genotype on the oral bioavailability of topotecan. Cancer Biology \& Therapy 4, 650-658.

126. Sparreboom, A., Gelderblom, H., Marsh, S., Ahluwalia, R., Obach, R., Principe, P., et al. (2004). Diflomotecan pharmacokinetics in relation to ABCG2 421C>A genotype. Clinical Pharmacology and Therapeutics, 76, 38-44.

127. Zamboni, W. C., Ramanathan, R. K., McLeod, H. L., Mani, S., Potter, D. M., Strychor, S., et al. (2006). Disposition of 9-nitrocamptothecin and its 9-aminocamptothecin metabolite in relation to $\mathrm{ABC}$ transporter genotypes. Investigational New Drugs, 24, 393-401.

128. Ross, D. D., Karp, J. E., Chen, T. T., \& Doyle, L. A. (2000). Expression of breast cancer resistance protein in blast cells from patients with acute leukemia. Blood, 96, 365-368.

129. Galimberti, S., Guerrini, F., Palumbo, G. A., Consoli, U., Fazzi, R., Morabito, F., et al. (2004). Evaluation of BCRP and MDR-1 co-expression by quantitative molecular assessment in AML patients. Leukemia Research, 28, 367-372.

130. van Der Kolk, D. M., Vellenga, E., Scheffer, G. L., Muller, M., Bates, S. E., Scheper, R. J., et al. (2002). Expression and activity of breast cancer resistance protein (BCRP) in de novo and relapsed acute myeloid leukemia. Blood, 99, 3763-3770.

131. Abbott, B. L., Colapietro, A. M., Barnes, Y., Marini, F., Andreeff, M., \& Sorrentino, B. P. (2002). Low levels of ABCG2 expression in adult AML blast samples. Blood, 100, 4594-4601.

132. van der Pol, M. A., Broxterman, H. J., Pater, J. M., Feller, N., van der Maas, M., Weijers, G. W., et al. (2003). Function of the $\mathrm{ABC}$ transporters, P-glycoprotein, multidrug resistance protein and breast cancer resistance protein, in minimal residual disease in acute myeloid leukemia. Haematologica, 88, 134-147.

133. Benderra, Z., Faussat, A. M., Sayada, L., Perrot, J. Y., Chaoui, D., Marie, J. P., et al. (2004). Breast cancer resistance protein and P-glycoprotein in 149 adult acute myeloid leukemias. Clinical Cancer Research, 10, 7896-7902.

134. Uggla, B., Stahl, E., Wagsater, D., Paul, C., Karlsson, M. G., Sirsjo, A., et al. (2005). BCRP mRNA expression v. clinical outcome in 40 adult AML patients. Leukemia Research, 29, 141-146.

135. Suvannasankha, A., Minderman, H., O'Loughlin, K. L., Nakanishi, T., Ford, L. A., Greco, W. R., et al. (2004). Breast cancer resistance protein (BCRP/MXR/ABCG2) in adult acute lymphoblastic leukaemia: Frequent expression and possible correlation with shorter disease-free survival. British Journal of Haematology, 127, 392-398.

136. Steinbach, D., Sell, W., Voigt, A., Hermann, J., Zintl, F., \& Sauerbrey, A. (2002). BCRP gene expression is associated with a poor response to remission induction therapy in childhood acute myeloid leukemia. Leukemia, 16, 1443-1447.

137. Stam, R. W., van den Heuvel-Eibrink, M. M., den Boer, M. L., Ebus, M. E., Janka-Schaub, G. E., Allen, J. D., et al. (2004). Multidrug resistance genes in infant acute lymphoblastic leukemia: Ara-C is not a substrate for the breast cancer resistance protein. Leukemia, 18, 78-83.
138. Sauerbrey, A., Sell, W., Steinbach, D., Voigt, A., \& Zintl, F. (2002). Expression of the BCRP gene (ABCG2/MXR/ABCP) in childhood acute lymphoblastic leukaemia. British Journal of Haematology, 118, 147-150.

139. Wilson, C. S., Davidson, G. S., Martin, S. B., Andries, E., Potter, J., Harvey, R., et al. (2006). Gene expression profiling of adult acute myeloid leukemia identifies novel biologic clusters for risk classification and outcome prediction. Blood, 108, 685-696.

140. Diestra, J. E., Scheffer, G. L., Catala, I., Maliepaard, M., Schellens, J. H., Scheper, R. J., et al. (2002). Frequent expression of the multi-drug resistance-associated protein BCRP/MXR/ $\mathrm{ABCP} / \mathrm{ABCG} 2$ in human tumours detected by the BXP-21 monoclonal antibody in paraffin-embedded material. Journal of Pathology, 198, 213-219.

141. Kanzaki, A., Toi, M., Nakayama, K., Bando, H., Mutoh, M., Uchida, T., et al. (2001). Expression of multidrug resistancerelated transporters in human breast carcinoma. Japanese Journal of Cancer Research, 92, 452-458.

142. Faneyte, I. F., Kristel, P. M., Maliepaard, M., Scheffer, G. L., Scheper, R. J., Schellens, J. H., et al. (2002). Expression of the breast cancer resistance protein in breast cancer. Clinical Cancer Research, 8, 1068-1074.

143. Burger, H., Foekens, J. A., Look, M. P., Meijer-van Gelder, M. E., Klijn, J. G., Wiemer, E. A., et al. (2003). RNA expression of breast cancer resistance protein, lung resistancerelated protein, multidrug resistance-associated proteins 1 and 2 , and multidrug resistance gene 1 in breast cancer: Correlation with chemotherapeutic response. Clinical Cancer Research, 9, 827-836.

144. Yoh, K., Ishii, G., Yokose, T., Minegishi, Y., Tsuta, K., Goto, K., et al. (2004). Breast cancer resistance protein impacts clinical outcome in platinum-based chemotherapy for advanced non-small cell lung cancer. Clinical Cancer Research, 10, 1691-1697.

145. Friedrich, R. E., Punke, C., \& Reymann, A. (2004). Expression of multi-drug resistance genes (mdr1, mrp 1, bcrp) in primary oral squamous cell carcinoma. In Vivo, 18, 133-147.

146. Zurita, A. J., Diestra, J. E., Condom, E., Garcia Del Muro, X., Scheffer, G. L., Scheper, R. J., et al. (2003). Lung resistancerelated protein as a predictor of clinical outcome in advanced testicular germ-cell tumours. British Journal of Cancer, 88, 879886.

147. Diestra, J. E., Condom, E., Del Muro, X. G., Scheffer, G. L., Perez, J., Zurita, A. J., et al. (2003). Expression of multidrug resistance proteins $\mathrm{P}$-glycoprotein, multidrug resistance protein 1 , breast cancer resistance protein and lung resistance related protein in locally advanced bladder cancer treated with neoadjuvant chemotherapy: Biological and clinical implications. Journal of Urology, 170, 1383-1387.

148. Bunting, K. D. (2002). ABC transporters as phenotypic markers and functional regulators of stem cells. Stem Cells, 20, 11-20.

149. Jonker, J. W., Freeman, J., Bolscher, E., Musters, S., Alvi, A. J., Titley, I., et al. (2005). Contribution of the ABC transporters Bcrp1 and Mdr1a/1b to the side population phenotype in mammary gland and bone marrow of mice. Stem Cells, 23, 1059-1065.

150. Hussain, S. Z., Strom, S. C., Kirby, M. R., Burns, S., Langemeijer, S., Ueda, T., et al. (2005). Side population cells derived from adult human liver generate hepatocyte-like cells in vitro. Digestive Diseases and Sciences, 50, 1755-1763.

151. Minor, D. R., Monroe, D., Damico, L. A., Meng, G., Suryadevara, U., \& Elias, L. (2002). A phase II study of thalidomide in advanced metastatic renal cell carcinoma. Investigational New Drugs, 20, 389-393.

152. Montanaro, F., Liadaki, K., Schienda, J., Flint, A., Gussoni, E., \& Kunkel, L. M. (2004). Demystifying SP cell purification: 
Viability, yield, and phenotype are defined by isolation parameters. Experimental Cell Research, 298, 144-154.

153. Patrawala, L., Calhoun, T., Schneider-Broussard, R., Zhou, J., Claypool, K., \& Tang, D. G. (2005). Side population is enriched in tumorigenic, stem-like cancer cells, whereas ABCG2+ and ABCG2- cancer cells are similarly tumorigenic. Cancer Research, 65, 6207-6219.

154. Beck, W. T., Grogan, T. M., Willman, C. L., Cordon-Cardo, C., Parham, D. M., Kuttesch, J. F., et al. (1996). Methods to detect P-glycoprotein-associated multidrug resistance in patients' tumors: Consensus recommendations. Cancer Research, 56, 3010-3020.

155. Glasgow, S. C., Yu, J., Carvalho, L. P., Shannon, W. D., Fleshman, J. W., \& McLeod, H. L. (2005). Unfavourable expression of pharmacologic markers in mucinous colorectal cancer. British Journal of Cancer, 92, 259-264.

156. Konig, J., Hartel, M., Nies, A. T., Martignoni, M. E., Guo, J., Buchler, M. W., et al. (2005). Expression and localization of human multidrug resistance protein $(\mathrm{ABCC})$ family members in pancreatic carcinoma. International Journal of Cancer, 115, 359-367.

157. van Den Heuvel-Eibrink, M. M., Wiemer, E. A., Prins, A., Meijerink, J. P., Vossebeld, P. J., Van Der Holt, B., et al. (2002). Increased expression of the breast cancer resistance protein $(B C R P)$ in relapsed or refractory acute myeloid leukemia (AML). Leukemia, 16, 833-839.

158. Nishiyama, K., Shirahama, T., Yoshimura, A., Sumizawa, T., Furukawa, T., Ichikawa-Haraguchi, M., et al. (1993). Expression of the multidrug transporter, p-glycoprotein, in renal and transitional cell carcinomas. Cancer, 71, 3611-3619.

159. Clarke, R., Leonessa, F., \& Trock, B. (2005). Multidrug resistance/P-glycoprotein and breast cancer: Review and metaanalysis. Seminars in Oncology, 32, S9-S15.

160. Robey, R. W., Fetsch, P. A., Polgar, O., Dean, M., \& Bates, S. E. (2006). The livestock photosensitizer, phytoporphyrin (phylloerythrin), is a substrate of the ATP-binding cassette transporter ABCG2. Research in Veterinary Science, 81, 345-349.

161. Martin, C. M., Meeson, A. P., Robertson, S. M., Hawke, T. J., Richardson, J. A., Bates, S., et al. (2004). Persistent expression of the ATP-binding cassette transporter, Abcg2, identifies cardiac SP cells in the developing and adult heart. Developmental Biology, 265, 262-275.

162. Theou, N., Gil, S., Devocelle, A., Julie, C., Lavergne-Slove, A., Beauchet, A., et al. (2005). Multidrug resistance proteins in gastrointestinal stromal tumors: Site-dependent expression and initial response to imatinib. Clinical Cancer Research, 11, 7593-7598.

163. Minderman, H., Suvannasankha, A., O'Loughlin, K. L., Scheffer, G. L., Scheper, R. J., Robey, R. W., et al. (2002). Flow cytometric analysis of breast cancer resistance protein expression and function. Cytometry, 48, 59-65.

164. Kawabata, S., Oka, M., Soda, H., Shiozawa, K., Nakatomi, K., Tsurutani, J., et al. (2003). Expression and functional analyses of breast cancer resistance protein in lung cancer. Clinical Cancer Research, 9, 3052-3057.

165. Minderman, H., Brooks, T. A., O’Loughlin, K. L., Ojima, I., Bernacki, R. J., \& Baer, M. R. (2004). Broad-spectrum modulation of ATP-binding cassette transport proteins by the taxane derivatives ortataxel (IDN-5109, BAY 59-8862) and tRA96023. Cancer Chemotherapy and Pharmacology, 53, 363-369.

166. Ozvegy-Laczka, C., Varady, G., Koblos, G., Ujhelly, O., Cervenak, J., Schuetz, J. D., et al. (2005). Function-dependent conformational changes of the ABCG2 multidrug transporter modify its interaction with a monoclonal antibody on the cell surface. Journal of Biological Chemistry, 280, 4219-4227.

167. Goda, K., Nagy, H., Mechetner, E., Cianfriglia, M., \& Szabo, G. $\mathrm{Jr}$ (2002). Effects of ATP depletion and phosphate analogues on
P-glycoprotein conformation in live cells. European Journal of Biochemistry, 269, 2672-2677.

168. Nobili, S., Landini, I., Giglioni, B., \& Mini, E. (2006). Pharmacological strategies for overcoming multidrug resistance. Current Drug Targets, 7, 861-879.

169. Ozvegy, C., Varadi, A., \& Sarkadi, B. (2002). Characterization of drug transport, ATP hydrolysis and nucleotide trapping by the human ABCG2 multidrug transporter: Modulation of substrate specificity by a point mutation. Journal of Biological Chemistry, 277, 47980-47990.

170. Nakanishi, T., Doyle, L. A., Hassel, B., Wei, Y., Bauer, K. S., Wu, S., et al. (2003). Functional characterization of human breast cancer resistance protein (BCRP, ABCG2) expressed in the oocytes of Xenopus laevis. Molecular Pharmacology, 64, 1452-1462.

171. Allen, J. D., Van Dort, S. C., Buitelaar, M., van Tellingen, O., \& Schinkel, A. H. (2003). Mouse breast cancer resistance protein (Bcrp1/Abcg2) mediates etoposide resistance and transport, but etoposide oral availability is limited primarily by $\mathrm{P}$-glycoprotein. Cancer Research, 63, 1339-1344.

172. Brangi, M., Litman, T., Ciotti, M., Nishiyama, K., Kohlhagen, G., Takimoto, C., et al. (1999). Camptothecin resistance: Role of the ATP-binding cassette (ABC), mitoxantrone-resistance halftransporter (MXR), and potential for glucuronidation in MXRexpressing cells. Cancer Research, 59, 5938-5946.

173. Allen, J. D., Brinkhuis, R. F., Wijnholds, J., \& Schinkel, A. H. (1999). The mouse Bcrp1/Mxr/Abcp gene: Amplification and overexpression in cell lines selected for resistance to topotecan, mitoxantrone, or doxorubicin. Cancer Research, 59, 4237-4241.

174. Rajendra, R., Gounder, M. K., Saleem, A., Schellens, J. H., Ross, D. D., Bates, S. E., et al. (2003). Differential effects of the breast cancer resistance protein on the cellular accumulation and cytotoxicity of 9-aminocamptothecin and 9-nitrocamptothecin. Cancer Research, 63, 3228-3233.

175. Maliepaard, M., van Gastelen, M. A., Tohgo, A., Hausheer, F. H., van Waardenburg, R. C., de Jong, L. A., et al. (2001). Circumvention of breast cancer resistance protein (BCRP)mediated resistance to camptothecins in vitro using non-substrate drugs or the BCRP inhibitor GF120918. Clinical Cancer Research, 7, 935-941.

176. Yang, C. H., Schneider, E., Kuo, M. L., Volk, E. L., Rocchi, E., \& Chen, Y. C. (2000). BCRP/MXR/ABCP expression in topotecanresistant human breast carcinoma cells. Biochemical Pharmacology, 60, 831-837.

177. Litman, T., Brangi, M., Hudson, E., Fetsch, P., Abati, A., Ross, D. D., et al. (2000). The multidrug-resistant phenotype associated with overexpression of the new $\mathrm{ABC}$ half-transporter, MXR (ABCG2). Journal of Cell Science, 113, 2011-2021.

178. Ishii, M., Iwahana, M., Mitsui, I., Minami, M., Imagawa, S., Tohgo, A., et al. (2000). Growth inhibitory effect of a new camptothecin analog, DX-8951f, on various drug-resistant sublines including BCRP-mediated camptothecin derivative-resistant variants derived from the human lung cancer cell line PC-6. Anticancer Drugs, 11, 353-362.

179. Schellens, J. H., Maliepaard, M., Scheper, R. J., Scheffer, G. L., Jonker, J. W., Smit, J. W., et al. (2000). Transport of topoisomerase I inhibitors by the breast cancer resistance protein. Potential clinical implications. Annals of the New York Academy of Sciences, 922, 188-194.

180. Nakatomi, K., Yoshikawa, M., Oka, M., Ikegami, Y., Hayasaka, S., Sano, K., et al. (2001). Transport of 7-ethyl-10-hydroxycamptothecin $(\mathrm{SN}-38)$ by breast cancer resistance protein ABCG2 in human lung cancer cells. Biochemical and Biophysical Research Communications, 288, 827-832.

181. Yoshikawa, M., Ikegami, Y., Sano, K., Yoshida, H., Mitomo, H., Sawada, S., et al. (2004). Transport of SN-38 by the wild type of human $\mathrm{ABC}$ transporter $\mathrm{ABCG} 2$ and its inhibition by quercetin, 
a natural flavonoid. Journal of Experimental Therapeutics \& Oncology, 4, 25-35.

182. Bates, S. E., Medina-Perez, W. Y., Kohlhagen, G., Antony, S., Nadjem, T., Robey, R. W., et al. (2004). ABCG2 mediates differential resistance to $\mathrm{SN}-38$ and homocamptothecins. Journal of Pharmacology and Experimental Therapeutics, 310, 836-842.

183. Volk, E. L., Farley, K. M., Wu, Y., Li, F., Robey, R. W., \& Schneider, E. (2002). Overexpression of wild-type breast cancer resistance protein mediates methotrexate resistance. Cancer Research, 62, 5035-5040.

184. Mitomo, H., Kato, R., Ito, A., Kasamatsu, S., Ikegami, Y., Kii, I., et al. (2003). A functional study on polymorphism of the ATPbinding cassette transporter ABCG2: Critical role of arginine-482 in methotrexate transport. Biochemical Journal, 373, 767-774.

185. Jonker, J. W., Buitelaar, M., Wagenaar, E., Van Der Valk, M. A., Scheffer, G. L., Scheper, R. J., et al. (2002). The breast cancer resistance protein protects against a major chlorophyllderived dietary phototoxin and protoporphyria. Proceedings of the National Academy of Sciences of the United States of America, 99, 15649-15654.

186. Robey, R. W., Steadman, K., Polgar, O., \& Bates, S. E. (2005). ABCG2-mediated transport of photosensitizers: Potential impact on photodynamic therapy. Cancer Biology \& Theraphy, 4, 187-194.

187. Gupta, A., Dai, Y., Vethanayagam, R. R., Hebert, M. F., Thummel, K. E., Unadkat, J. D., et al. (2006). Cyclosporin A, tacrolimus and sirolimus are potent inhibitors of the human breast cancer resistance protein $(\mathrm{ABCG} 2)$ and reverse resistance to mitoxantrone and topotecan. Cancer Chemotherapy and Pharmacology, 58(3), 374-383.

188. Qadir, M., O'Loughlin, K. L., Fricke, S. M., Williamson, N. A., Greco, W. R., Minderman, H., et al. (2005). Cyclosporin A is a broad-spectrum multidrug resistance modulator. Clinical Cancer Research, 11, 2320-2326.

189. Nakamura, Y., Oka, M., Soda, H., Shiozawa, K., Yoshikawa, M., Itoh, A., et al. (2005). Gefitinib ("Iressa", ZD1839), an epidermal growth factor receptor tyrosine kinase inhibitor, reverses breast cancer resistance protein/ABCG2-mediated drug resistance. Cancer Research, 65, 1541-1546.

190. Braun, A. H., Stark, K., Dirsch, O., Hilger, R. A., Seeber, S., \& Vanhoefer, U. (2005). The epidermal growth factor receptor tyrosine kinase inhibitor gefitinib sensitizes colon cancer cells to irinotecan. Anticancer Drugs, 16, 1099-1108.

191. Ozvegy-Laczka, C., Hegedus, T., Varady, G., Ujhelly, O., Schuetz, J. D., Varadi, A., et al. (2004). High-affinity interaction of tyrosine kinase inhibitors with the ABCG2 multidrug transporter. Molecular Pharmacology, 65, 1485-1495.

192. Houghton, P. J., Germain, G. S., Harwood, F. C., Schuetz, J. D., Stewart, C. F., Buchdunger, E., et al. (2004). Imatinib mesylate is a potent inhibitor of the ABCG2 (BCRP) transporter and reverses resistance to topotecan and $\mathrm{SN}-38$ in vitro. Cancer Research, 64, 2333-2337.

193. Imai, Y., Tsukahara, S., Ishikawa, E., Tsuruo, T., \& Sugimoto, Y. (2002). Estrone and 17beta-estradiol reverse breast cancer resistance protein-mediated multidrug resistance. Japanese Journal of Cancer Research, 93, 231-235.

194. Sugimoto, Y., Tsukahara, S., Imai, Y., Sugimoto, Y., Ueda, K., \& Tsuruo, T. (2003). Reversal of breast cancer resistance proteinmediated drug resistance by estrogen antagonists and agonists. Molecular Cancer Therapeutics, 2, 105-112.

195. Jekerle, V., Klinkhammer, W., Scollard, D. A., Breitbach, K., Reilly, R. M., Piquette-Miller, M., et al. (2006). In vitro and in vivo evaluation of WK-X-34, a novel inhibitor of P-glycoprotein and BCRP, using radio imaging techniques. International Journal of Cancer, 119, 414-422.

196. Limtrakul, P., Chearwae, W., Shukla, S., Phisalphong, C., \& Ambudkar, S. V. (2006). Modulation of function of three ABC drug transporters, P-glycoprotein (ABCB1), mitoxantrone resistance protein $(\mathrm{ABCG} 2)$ and multidrug resistance protein 1 (ABCC1) by tetrahydrocurcumin, a major metabolite of curcumin. Molecular and Cellular Biochemistry.

197. Chearwae, W., Shukla, S., Limtrakul, P., \& Ambudkar, S. V. (2006). Modulation of the function of the multidrug resistancelinked ATP-binding cassette transporter ABCG2 by the cancer chemopreventive agent curcumin. Molecular Cancer Therapeutics, 5, 1995-2006.

198. Zhang, Y., Gupta, A., Wang, H., Zhou, L., Vethanayagam, R. R., Unadkat, J. D., et al. (2005). BCRP transports dipyridamole and is inhibited by calcium channel blockers. Pharmaceutical Research, 22, 2023-2034.

199. Sargent, J. M., Williamson, C. J., Maliepaard, M., Elgie, A. W., Scheper, R. J., \& Taylor, C. G. (2001). Breast cancer resistance protein expression and resistance to daunorubicin in blast cells from patients with acute myeloid leukaemia. British Journal of Haematology, 115, 257-262.

200. Suvannasankha, A., Minderman, H., O'Loughlin, K. L., Nakanishi, T., Greco, W. R., Ross, D. D., et al. (2004). Breast cancer resistance protein (BCRP/MXR/ABCG2) in acute myeloid leukemia: Discordance between expression and function. Leukemia, 18, 1252-1257.

201. Plasschaert, S. L., Van Der Kolk, D. M., De Bont, E. S., Vellenga, E., Kamps, W. A., \& De Vries, E. G. (2004). Breast cancer resistance protein (BCRP) in acute leukemia. Leukemia and Lymphoma, 45, 649-654.

202. Scheffer, G. L., Maliepaard, M., Pijnenborg, A. C., van Gastelen, M. A., de Jong, M. C., Schroeijers, A. B., et al. (2000). Breast cancer resistance protein is localized at the plasma membrane in mitoxantrone- and topotecan-resistant cell lines. Cancer Research, 60, 2589-2593.

203. Aust, S., Obrist, P., Jaeger, W., Klimpfinger, M., Tucek, G., Wrba, F., et al. (2004). Subcellular localization of the ABCG2 transporter in normal and malignant human gallbladder epithelium. Laboratory Investigation, 84, 1024-1036.

204. Deichmann, M., Thome, M., Egner, U., Hartschuh, W., \& Kurzen, H. (2005). The chemoresistance gene ABCG2 (MXR/ $\mathrm{BCRP} 1 / \mathrm{ABCP} 1)$ is not expressed in melanomas but in single neuroendocrine carcinomas of the skin. Journal of Cutaneous Pathology, 32, 467-473. 